\title{
Marbury and the Constitutional Mind: A Bicentennial Essay on the Wages of Doctrinal Tension
}

\section{Citation}

Richard H. Fallon Jr., Marbury and the Constitutional Mind: A Bicentennial Essay on the Wages of Doctrinal Tension, 91 Calif. L. Rev. 1 (2003).

\section{Published Version}

http://scholarship.law.berkeley.edu/californialawreview/vol91/iss1/1/

\section{Permanent link}

http://nrs.harvard.edu/urn-3:HUL.InstRepos:12942286

\section{Terms of Use}

This article was downloaded from Harvard University's DASH repository, and is made available under the terms and conditions applicable to Other Posted Material, as set forth at http:// nrs.harvard.edu/urn-3:HUL.InstRepos:dash.current.terms-of-use\#LAA

\section{Share Your Story}

The Harvard community has made this article openly available. Please share how this access benefits you. Submit a story.

Accessibility 


\section{California Law Review}

Volume 91 | Issue 1

Article 1

$1-31-2003$

\section{Marbury and the Constitutional Mind: A Bicentennial Essay on the Wages of Doctrinal Tension}

Richard H. Fallon Jr.

rfallon@law.harvard.edu

Follow this and additional works at: http://scholarship.law.berkeley.edu/californialawreview

Part of the Law Commons

\section{Recommended Citation}

Richard H. Fallon Jr., Marbury and the Constitutional Mind: A Bicentennial Essay on the Wages of Doctrinal Tension, 91 CAL. L. REv. 1 (2003).

Available at: http://scholarship.law.berkeley.edu/californialawreview/vol91/iss1/1

This Article is brought to you for free and open access by the California Law Review at Berkeley Law Scholarship Repository. It has been accepted for inclusion in California Law Review by an authorized administrator of Berkeley Law Scholarship Repository. For more information, please contact jcera@law.berkeley.edu. 


\title{
California Law Review
}

\begin{tabular}{llc}
\hline \hline Vol. 91 & JANUARY 2003 & No. 1 \\
\hline \hline
\end{tabular}

Copyright $\odot 2003$ by California Law Review, Inc.

\section{Marbury and the Constitutional Mind: A Bicentennial Essay on the Wages of Doctrinal Tension}

\author{
Richard H. Fallon, Jr. $\dagger$
}

\section{TABLE of Contents}

Introduction.

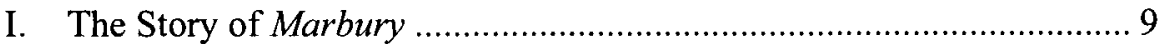

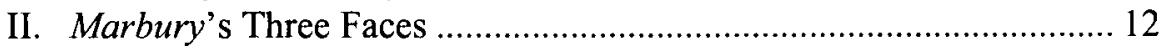

A. The Three Faces Emerging from Marbury's Reasoning .............. 12

1. The Private-Rights Face .................................................... 12

2. The Special-Functions Face ............................................... 14

3. The Political or Prudential Face ............................................. 16

B. The Continuing Influence of the Three Faces in Modern

Constitutional Practice ................................................................. 20

1. The Influence of the Private-Rights Face .............................. 20

2. The Influence of the Special-Functions Face ......................... 23

3. The Influence of the Political or Prudential Face ................... 27

III. Conflicts Among the Faces ................................................................ 33

IV. Strategies for Making Sense of Dissonance ...................................... 36

A. The Nature of the Challenge …….................................................. 37

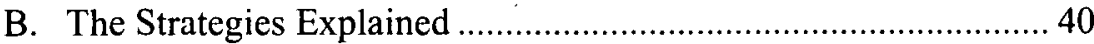

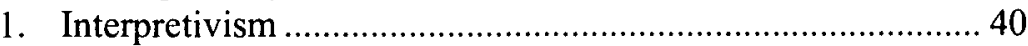

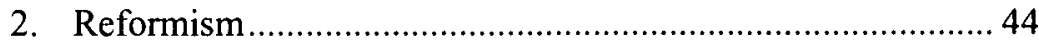

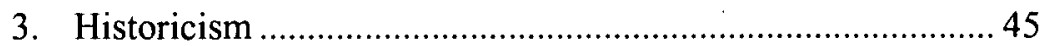

Copyright $(02003$ California Law Review, Inc. California Law Review, Inc. (CLR) is a California nonprofit corporation. CLR and the authors are solely responsible for the content of their publications.

$\dagger \quad$ Professor of Law, Harvard Law School. 1 am grateful to David Barron, Jerry Frug, Frank Michelman, Dan Meltzer, and David Shapiro for helpful comments on a previous draft of this essay and to Mark Freeman, Kevin Walsh, and Davis Wang for valuable research and editorial assistance. 


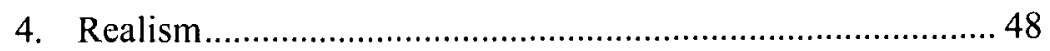

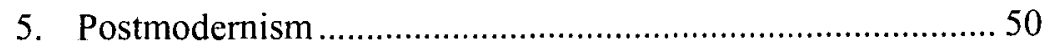

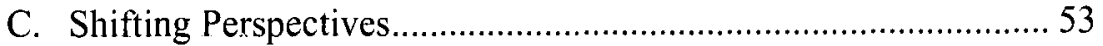

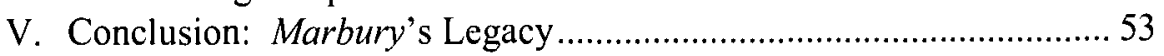




\title{
Marbury and the Constitutional Mind: A Bicentennial Essay on the Wages of Doctrinal Tension
}

\author{
Richard H. Fallon, Jr.
}

Bicentennial celebrations of Marbury v. Madison should recognize Marbury's influence in shaping a body of constitutional law that is not only rich and diverse but also tension-ridden. Marbury furnishes the canonical statement of the judicial role, but that statement is multiple, not singular. Specifically, Marbury exhibits three distinct faces. A "private-rights" face asserts that courts must decide constitutional issues when, but only when, necessary to adjudicate traditional disputes involving concrete injuries. A "special-functions" face implies that courts have a broader role in enforcing constitutional norms. A "political" or "prudential" face, which is suggested by Marbury's surrounding facts, counsels that courts should sometimes tailor their rulings to avoid collision with the political branches. Marbury's three faces frequently yield conflicting prescriptions. What is more, all help to shape contemporary constitutional law. The result is widespread doctrinal tension. In the literature on constitutional law and theory, varied strategies have emerged for dealing with the challenges and cognitive dissonance that doctrinal tension generates. Some strategies seek to establish doctrinal coherence through creative interpretation, policydriven reform, or historical reconstruction. Others attempt to explain and disarm doctrinal conflict. But no one strategy can satisfy all of the demands for ordered understanding that a participant in constitutional practice might reasonably assert. Richness and diversity are the glory of Marbury's legacy, but tension and methodological disagreement are also integral to its heritage.

\section{INTRODUCTION}

This is an essay about tensions and apparent contradiction, and about strategies for dealing with tensions and apparent contradiction, at the foundations of constitutional law. I begin with the assumption that most participants in constitutional discourse experience it as including doctrinal tensions that sometimes appear to devolve into outright contradictions.' 
Commentators sometimes attribute doctrinal tensions to the distinctive failures of the Supreme Court during particular eras. ${ }^{2}$ But the problem, if that be the word, is more foundational. No case more aptly demonstrates deep-rooted tensions in constitutional law than Marbury v. Madison, ${ }^{3}$ and I shall treat Marbury and doctrines that trace to it as paradigmatic.

As Marbury's forthcoming bicentennial reminds us, this decision occupies a unique status in the constitutional mind. If viewed as the case establishing judicial review, Marbury has a foundational, even constitutive role in constitutional jurisprudence. ${ }^{4}$ Take away Marbury, and constitutional doctrine as we know it would disappear. As historians have pointed out, the portrayal of Marbury as uniquely or even principally responsible for judicial review is probably simplistic, ${ }^{5}$ but even if the received teaching

Procedure, 33 AM. CRIM. L. Rev. 1123,1126 (1996) ("[A]t the level of Supreme Court doctrine . . constitutional criminal procedure is, to put it bluntly, a mess."); Mitchell N. Berman, Commercial Speech and the Unconstitutional Conditions Doctrine: A Second Look at "The Greater Includes The Lesser", 55 VAND. L. Rev. 693, 763 (2002) ("Existing commercial speech doctrine is a mess."); John C. Jeffries, Jr., In Praise of the Eleventh Amendment and Section I983, 84 VA. L. REv. 47, 47 (1998) ("As everyone knows, the Eleventh Amendment is a mess."); William Michacl Treanor, Jam for Justice Holmes: Reassessing the Significance of Mahon, 86 GEo. L.J. 813, 871 (1998) (noting scholars' general agreement that the doctrine of constitutional takings "incorporates a serics of approaches that, as has been often pointed out, conflict with each other and make takings law a 'mess'"). Justiccs of the Supreme Court also note and decry contradictions in constitutional doctrine, albeit rarely in opinions for the Court. See, e.g., Romano v. Oklahoma, 512 U.S. 1, 6 (1994) (describing the requirements of Eighth Amendment doctrine in death penalty cases as "somewhat contradictory"); Church of Lukumi Babalu Aye, Inc. v. City of Hialeah, 508 U.S. 520, 573-74 (1992) (Souter, J., concurring in part and concurring in the judgment) (arguing that Employment Div. v. Smith, 494 U.S. 872 (1990), crcated an "intolerable tension" in free-exercise doctrinc).

2. See, e.g., Alexander M. Bickel, The Supreme Court and the Idea of Progress 81 (1970) (criticizing "the Warrcn Court's refusal, too often, to submit to the discipline of the analytically tenable distinction, and . . . other failings of a like character"); Vincent Blasi, The Rootless Activism of the Burger Court, in The Burger Court: The Counter Revolution that Wasn't 198-217 (Vincent Blasi ed., 1983) (discussing doctrinal and methodological tensions arising from the "rootless activism" of the Burger Court); Charles Fried, Revolutions?, 109 HARV. L. Rev. 13, 76-77 (1995) (suggesting that the Rehnquist Court "may be clearing away" the "detritus" left by the less principled Warren and Burgcr Courts).

3. 5 U.S. (1 Cranch) 137 (1803).

4. See, e.g., Cooper v. Aaron, 358 U.S. 1, 17-19 (1958) ("This decision [Marbury] declared the basic principle that the federal judiciary is supreme in the exposition of the law of the Constitution, and that principle has ever since been respected by this Court and the Country as a pcrmancnt and indispensablc feature of our constitutional system."); PaUl W. Kahn, The Reign of LAW: MarbuRY v. MADISON AND THE CONSTITUTION OF AMERICA 4 (1997) ("Marbury is a canonical text of constitutional law" with which "the study of constitutional law" both begins and ends.); Henry P. Monaghan, Marbury and the Administrative State, 83 CoLum. L. Rev. 1, 7 (1983) (terming Marbury's establishment of the law-declaring duty of the judicial branch "a cornerstone of the American constitutional order").

5. At the Constitutional Convention, the delegates seem to have taken for granted that the courts would havc a powcr of judicial review of at least some scope. See Richard H. Fallon, JR. ET al., Hart \& Wechsler's the Federal Courts and the Federal System 11 (4th ed. 1996). During the ratification debates, Hamilton defended such a powcr in Federalist No. 78. See The Federalist No. 78, at 467 (A. Hamilton) (Clinton Rossiter ed., 1961). And prior to Marbury, as David Currie has cmphasized, the Justices had either exercised or presupposed a power of judicial review in several notable cases. 
about Marbury is part myth, that myth has become real in constitutional doctrine and surrounding practices of argument. Within those practices, Marbury not only rcpresents the fountainhead of judicial review, but also furnishes the canonical statement of the necessary and appropriate role of courts in the constitutional scheme.

I shall argue in this Article, however, that Marbury's canonical statement is multiple, not singular, in its portrayal of the judicial function in constitutional adjudication. More specifically, the mythic Marbury that suffuses constitutional jurisprudence has what I shall characterize as three faces: a private-rights face, a special-functions face, and a prudential face. These three faces generate prescriptions that appear to contradict one another.

For anyone with an "internal" point of view on constitutional practice, reflecting the outlook of an engaged participant in constitutional argument, ${ }^{6}$ tensions in constitutional doctrine are likely to generate the

The Supreme Court itself had measured a state law against a state constitution in Cooper v. Telfair [4 U.S. (4 Dall.) 14 (1800)] and Yad struck down another under the supremaey clause in Ware v. Hylton [3 U.S. (3 Dall.) 199 (1796)]; in both cases the power of judicial review was expressly affirmed. Even Acts of Congress had been struck down by federal circuit courts, and the Supreme Court, while purporting to reserve the question of its power to do so, had reviewed the constitutionality of a federal statute in Hylton v. United States [3 U.S. (3 Dall.) 171 (1796)]. Justice James Iredell had explicitly asserted this power both in Chisholm v. Georgia [2 U.S. (2 Dall.) 419 (1793)] and in Calder v. Bull [3 U.S. (3 Dall.) 386 (1798)], and Chase had acknowledged it in Cooper.... Yet though Marshall's principal arguments echoed those of Hamilton [in Federalist No. 78], he made no mention of any of this material, writing as if the question had never arisen before.

David Currie, The Constitution in the Supreme Court: The Powers of the Federal Courts, 1801-1835, 49 U. CHI. L. REv. 646, 655-56 (1982).

It has also been suggested that Marbury offered no guidance with respect to the most important question about judicial review that actually needed resolution: Pursuant to what standards could courts hold acts of Congress to be constitutionally invalid? See AleXANDER Bickel, THE LeAst Dangerous Branch: The Supreme Court at The Bar of Politics 73 (1962) (noting that Marbury is premised on the false assumption that the Constitution gives "plain and specific answers to concrete questions"). According to Sylvia Snowiss, "Marshall's key innovations did not come in Marbury," in whieh he said little about how the Constitution should be interpreted, but in opinions of the $1810 \mathrm{~s}$ and $1820 \mathrm{~s}$ in which he subjected the Constitution to "rules for statutory interpretation" and "transformed explicit fundamental law, different in kind from ordinary law, into supreme written law, different only in degree." Sylvia Snowiss, Judicial Review and the Law of the Constitution 3-4 (1990).

6. Engaged partieipants include not only judges and lawyers, but also citizens participating in constitutional debate. See J.M. Balkin, Understanding Legal Understanding: The Legal Subject and the Problem of Legal Coherence, 103 YALE L.J. 105, 128 (1993) (noting that "there are many different types of 'participants"); see also Ronald DWORKIN, LAW's EMPIRE 13-14 (1986) (deseribing an internal point of view and contrasting it with the "external point of view" that an anthropologist or historian might adopt in studying a remote culture). Dworkin's distinction between internal and external points of view, which 1 follow, reflects an earlier, implieit distinction drawn by Herbert Hart in maintaining that legal and social rules have an "internal aspect" in addition to "the regular uniform behaviour which an observer could record." HerberT LIONEl AdOlphus Hart, The CONCEPT of LAW 55 (1961). For further discussion of the notion of an internal point of view, see infra text accompanying notes 193-99. 
"inconsistency-produced discomfort" known as cognitive dissonance. According to the theory of cognitive dissonance, "we have, built into the workings of our mind, a mechanism that creates an uncomfortable feeling of dissonance, or lack of harmony, when we become aware of some inconsistency among the various attitudes, beliefs, and items of knowledge that constitute our mental store." Cognitive dissonance is likely because participants in constitutional practice are generally socialized to assume that legal doctrine is action-guiding; ${ }^{9}$ it furnishes binding norms of conduct. This assumption underlies doctrinally based arguments about how courts ought to decide cases, ${ }^{10}$ and it provides a necessary foundation for criticism of officials' conduct and judicial decisions. Doctrinal tensions and apparent contradictions threaten this assumption. If competing doctrinal formulations contradict one another, both eannot supply premises for valid legal arguments because contradictory premises cannot both be true. When participants in constitutional argument become aware of tensions among their beliefs, cognitive dissonance theory holds that the resulting discomfort will "motivate[] us to seek ways to resolve contradictions or inconsistencies among our cognitions."

Focusing on doctrinal tensions traceable to Marbury $v$. Madison, in this Article 1 shall identify a number of strategies for dealing with tensions and apparent contradiction in constitutional doctrine. These include what 1 shall describe as interpretivist, reformist, historicist, realist, and postmodernist approaches. Though my characterizations are somewhat stylized, each of these strategies reflects positions and assumptions familiar from the literature, even if my labels are sometimes idiosyncratic. Each strategy has evident appeal. But none, I shall argue, can satisfy all of the criteria that a reasonable person might apply to assess strategies for responding to tension and apparent contradiction in constitutional doctrine. The reason, in a

7. Rita L. Atkinson et al., Introduction to Psychology 735 (1 l th ed. 1993). For a subtle and sophistieated exploration of how cognitive dissonance may affect efforts by law students and others to understand legal doctrine, see Balkin, supra note 6.

8. Peter Gray, Psychology 520 (4th ed. 2002).

9. See Marin Roger Scordato, The Dualist Model of Legal Teaching and Scholarship, 37 АM. U. L. REv. 367, 389 (1990) (noting that "Iaw professors face powerful incentives to present legal doctrine and legal processes as being fundamentally rational, eoherent, and consistent with current notions of sound public policy" and that "law students frequently carry with them into class powerful assumptions about the coherence, rationality, and substantiveness of legal rules and legal doctrine").

I0. See Ronald Dworkin, Taking Rights Seriously 279-90 (I977) (arguing that legal argument and reasoning presuppose the existence of a single "right" and binding answer even to the most controverted legal questions); Steven D. Smith, Believing Like a Lawyer, 40 B.C. L. REv. 1041, 1069 (1999) (noting that the "aetual practices and presuppositions of lawyerly arguments seem to betray a sort of faith in some metaphysical abstraction called 'the law"').

11. Gray, supra note 8, at 520. The theory traces to Leon Festinger, A Theory of Cognitive DisSONANCE (1957). Since its introduction, the theory has been "one of the most influential theories in social psychology." Eddie Harmon-Jones \& Judson Mills, An Introduction to Cognitive Dissonance Theory and an Overview of Current Perspectives on the Theory, in Cognitive Dissonance: Progress on a Pivotal Theory in Social Psychology 3 (Eddie Harmon-Jones \& Judson Mills eds., 1999). 
nutshell, is that "the problem" presented by tension or apparent contradiction is partly one of knowing how to carry on with constitutional argument, but also partly one of individual psychology. In response to the cognitive dissonance created by doctrinal tension, each participant in constitutional practice will need to reconstruct a reasonable harmony among her own beliefs. But different people will bring different beliefs and purposes to their reconstructive projects. What counts as the best perspective from which to achieve a reconstruction will thus, inevitably, involve variables of purpose and psychology as well as the strictures of intellectual rigor.

Upon discovering tension at the foundation of constitutional doctrine, some participants in constitutional argument feel a strong impetus to identify an actual or potential, even if hidden, doctrinal harmony. ${ }^{12}$ For them, it would be disturbing, even repugnant, to participate in a politically important practice that pretends to logical rigor ${ }^{13}$ but frequently can generate no conclusive arguments ${ }^{14}$ due to the availability of contradictory premises. For anyone who experiences this psychological reaction yet wants to continue with constitutional argument, a perspective on doctrinal tension will not be acceptable unless it promiscs resolution of apparent contradiction. But there are various ways in which tension might be removed, either through creative interpretation of existing doctrine or through systemic or doctrinal reform. Those committed to the purging of tension will predictably disagree among themselves about how best to establish harmony.

After an initial shock of cognitive dissonance, othcrs find it easier to accept that constitutional practice is tension-ridden and to participate in it nonetheless. For example, those disposed to be deeply critical of the prevailing legal order may adopt the charge of normative incoherence as a further ground for indictment. ${ }^{15}$ Regarding current doctrine as conflicted, thcy may participate in constitutional practice with the aspiration of achieving reforms. Or they may simply seek a predictive theory of how judges actually decide cases, possibly on the basis of extradoctrinal variablcs. Other people, sometimes characterized as postmodernists, ${ }^{16}$ belie:e contradiction to be a pervasive feature of contemporary life and thought. For

12. See Balkin, stura note 6 , at $146-50$ (exploring reasons why some people "have a personal stake in the coherence of the legal system or parts of the legal system").

13. See Duncan Kennedy, A Critique of Adjudication (Fin de Siècle) 366 (1997) (noting that law students learn that the mode of speech appropriate to adjudication "presupposes that there is a correct legal answer to the question" and that the discourse answering this question is "necessitarian"); Smith, supra note 10, at 1042 (noting that lawyers and judges continue to justify their conclusions virtually exclusively by "purporting to extract from [a] conglomeration of materials univocal conclusions about what 'the law' really is").

14. See KENNEDY, supra note 13, at 311-12 (describing people who experience loss of faith in the power of legal reasoning as similar to a loss of faith in God).

15. See Balkin, supra note 6 , at 150 (observing that people who find "aspects of the law unjust ... are likely to find them lacking in coherence as well").

16. See infra text accompanying notes 258-73. 
them, it may be possible to assimilate the acceptance of irreducible legal tension to their more general understanding of language, culture, and human personality.

Even among those who find it psychologically easy to accept doctrinal tension or contradiction, there remain incentives for lawyers to argue to courts, and for courts to respond, as if they believed that the tension was only apparent, not real, and that beneath the surface lies an immanent doctrinal order. To say this is only to recall the initial source of cognitive dissonance: Formal constitutional argument characteristically purports to move from valid premises to determinate conclusions. But it is possible to advance constitutional arguments without truly believing what the arguments appear to presuppose. It is also familiar for participants in constitutional discourse to switch their perspectives on doctrinal tension from time to time and from role to role. A realist at one moment, who believes that judges are free to choose how to decide cases, may at the next moment offer arguments, in a brief or before a court, maintaining that one position is constitutionally necessary.

In light of the variety of individual psychological responses to perceived doctrinal tension, there can be no single, demonstrably correct way to study, understand, or attempt to make sense of constitutional law. The resulting diversity of approaches produces what can be viewed either as remarkable richness or numbing cacophony. The overarching aim of this Article is to shed light on this state of affairs.

The argument unfolds as follows. Part I recites the familiar facts of Marbury v. Madison and discusses the case's foundational role in constitutional jurisprudence. Part II then argues that Marbury's canonical characterization of the judicial role includes a private-rights face, a specialfunctions face, and a prudential face, each reflected in current constitutional doctrine. Part III argues that Marbury's three faces point in different directions; they offer conflicting prescriptions concerning the judicial role in implcmenting the Constitution. Part IV develops the thesis that tensions and conflict at the foundations of constitutional doctrine, such as those introduced by Marbury, give rise to cognitive dissonance and a resulting search for strategies to alleviate it. Part IV sketches five leading strategies. It explains the allure of cach, but also argues that none can be proved superior to the others by conclusive arguments procceding from shared premises. Part $\mathrm{V}$ provides a brief conclusion, asserting that the upshot of the tension at the foundations of constitutional doctrine is diversity in constitutional argument and outlook as well as irreducible methodological disagreement. 


\section{I}

\section{The STORY OF MARBURY}

For nearly all students of the judicial role under the American Constitution, Marbury marks a triumphant beginning. ${ }^{17}$ History has witnessed profound and recurring debates about how the courts should interpret the Constitution and, in particular, about when they should hold acts of Congress unconstitutional. ${ }^{18}$ But it seems largely undoubted that judicial review, correctly practiced, is part of the genius of the constitutional order. ${ }^{19}$

If judicial review is widely seen as successful, Marbury's facts are almost irresistible to any narrator of its history. ${ }^{20}$ In the early years of the republic, party divisions threatened to scuttle the nascent experiment in national government under a written constitution. After the bitter election of 1800, the defeated lame-duck Federalists quickly authorized and then ratified the appointments of a wave of "midnight" judges, virtually all loyalists of their defeated party. ${ }^{21}$ Also in high dudgeon, the incoming Jeffersonians seemed equally prepared to violate the Constitution's spirit, if not its letter, by eliminating judgeships ${ }^{22}$ and impeaching Federalist judges at least partly for partisan reasons. ${ }^{23}$ In this charged atmosphere, the Federalist William Marbury filed suit in the Supreme Court seeking a writ of mandamus directing James Madison, the secretary of state in the recently installed Jcfferson administration, to tender him the commission as a justice of the peace that had somehow failed to be delivered to him during the last days of the Adams administration.

17. See, e.g., BICKEL, supra note 5, at 74 ("Marbury v. Madison . . exerts an enormous magnetic pull. It is, after all, a great historic event, a famous victory; and it constitutes, even more than victories won by arms, one of the foundation stones of the Republic. It is hallowed.").

18. For an intellectual history of American constitutional theory, see PAUL W. KaHN, Legitimacy and History: Self-Government in American Constitutional Theory (1992).

19. See, e.g., Robert G. McCloskey, The American Supreme Court 228-29 (I960) (asserting that "surely American democracy would be poorer" without judicial review). There are, however, important recent skeptical treatments of judicial review. See, e.g., Mark V. TUSHNET, Taking the Constitution Away from the Courts (1999); Jeremy Waldron, LaW and DISAGREEMENT (1999).

20. For useful sketches of Marbury's historical background and context, see Richard E. Ellis, The Jeffersonian Crisis: Courts and Politics in the Young Republic (I97I); Kahn, supra note 4, at 9-17; James F. Simon, What Kind of Nation: Thomas JefFerson, John Marshall, and the Epic Struggle to Create a United States 104-90 (2002); 1 Charles Warren, The Supreme Court in United States History I55-230 (1922); James M. O'Fallon, Marbury, 44 Stan. L. ReV. 219 (1992).

21. See McCloskeY, supra note 19, at 39-41; Simon, supra note 20, 147-50, 173-74.

22. The judgeships were eliminated by the Act of March 8,1802 , ch. 8, $\$ 1,2$ Stat. I32, and the repeal act was allowed to stand in Stuart v. Laird, 5 U.S. (1 Cranch) 299 (1803), decided just six days after Marbury.

23. See Simon, supra note 20, at 191-219 (describing actual and threatened impeachment proceedings). 
With politically motivated expansions and contractions of the federal bench and the prospect of politically driven impeachments already menacing the constitutional aim of an independent, nonpartisan, and eo-equal judiciary, Marbury's suit against Madison threatened to elicit a knockout blow. If the Supreme Court headed by the newly confirmed Federalist Chief Justice John Marshall ruled for Marbury, it was widely expected that Madison, at Jefferson's direction, would ignore the decision. ${ }^{24}$ Aceording to Marshall's biographer, "Jefferson would have denounced the illegality of such a decision and laughed at the court's predicament." 25 The Court would have been powerless to enforce its judgment, and the precedent of executive defiance might have diminished the Court irreparably. If, however, the Court transparently yielded to the political threat and gave a supine ruling for Madison, that precedent would also have boded badly for judicial independenee.

With the role of the courts thus in the balance, Marshall ingeniously engineered a decision that gave formal victory to Madison, but rested on a foundation of judicial power, not impotence. In a performance of stunning bravura, Marshall first established that Marbury had a right to his commission. ${ }^{26} \mathrm{He}$ then coupled an inspiring claim about the commitment of the legal order to preserving private rights with an equally bold statement concerning the indispensable role of courts in the constitutional scheme: For every right, there must be a judicial remedy. ${ }^{27}$ Only then did he undertake to extricate himself from the looming collision with reigning political forces. He did so by holding that the Supreme Court lacked jurisdiction to grant Marbury the remedy to which he had a right. ${ }^{28}$

Marshall began his jurisdictional analysis by construing a provision of the 1789 Judiciary $\mathrm{Act}^{29}$ as attempting to confer original Supreme Court jurisdiction over all cases, such as Marbury's, in which the plaintiff sought a writ of mandamus. ${ }^{30}$ Marshall then reasoned that this attempted conferral created a constitutional issue. By design, the Supreme Court is almost exclusively an appellate court, structured to review the decisions of lower courts. In only a few categories of cases does the Constitution state

24. See Dean Alfange, Jr., Marbury v. Madison and Original Understandings of Judicial Review: In Defense of Traditional Wisdom, 1993 Sup. CT. Rev. 329, 383.

25. 3 albert J. Beveridge, The Life of John Marshall: Conflict and Construction, $1800-1815$, at 127 (1919).

26. Marbury v. Madison, 5 U.S. (1 Cranch) 137, 162 (1803).

27. Id. at 163 .

28. Id. at $176-80$.

29. Act of September 24, 1789, 1 Stat. 73 (1845).

30. See Marbury, 5 U.S. at 173 (finding that the ease comes within the provision of the 1789 Judiciary Act authorizing the Supreme Court to issue writs of mandamus). 
expressly that the Supreme Court may function as a trial court. ${ }^{31}$ Marbury's suit agr inst Madison did not come within any of those categories. And the listed categories, Marshall ruled, were intended to be exclusive.

Within Marshall's intricate frame, the dispositive question in Marbury thus became whether a congressionally enacted statute could bind the Supreme Court to exercise a jurisdiction forbidden by the Constitution. It was only by giving a negative answer to this question, and thereby claiming authority to engage in judicial review of the constitutionality of acts of Congress, that the Court could rule against Marbury and in favor of Madison.

By framing and resolving the issues as he did, Marshall turned Marbury v. Madison into an enormous strategic victory for judicial power. By squarely placing the holding on the ground that the Constitution forbade Supreme Court jurisdiction, he set an enduring precedent of judicial review. But because Marbury received no remedy, there was no judicial command to the executive branch for Madison to defy or for opponents of judicial power to denounce.

Marbury's dramatic facts explain the case's capacity to enthrall students of history, but the decision holds a further power for students of law. Within the fields of constitutional law and federal courts law, Marbury is not merely a case of historical importancc, but a living paradigm of the necessary and proper function of courts in exercising judicial review. ${ }^{32}$ For contemporary judges, lawyers, law professors, and law students, Marbury epitomizes the role that the judicial branch can, should, and must play under the American Constitution. In doing so, it structures traditional thinking about the judicial function.

To be a constitutional lawyer is to participate in a practice that is substantially founded on Marbury. ${ }^{33}$ There is no stronger constitutional argument against a position than that it contravenes Marbury's central holding; Marbury is too foundational, too ensconced, and too pervasive in influence to be rejected as mistaken. ${ }^{34}$ Correspondingly, perhaps the strongest argument of principle in favor of a disputed constitutional position is that Marbury entails it. Again, the rejection of Marbury is unthinkable. Instead,

31. See U.S. Const. art. 111, $\S 2$, cl. 2 ("In all Cases affecting Ambassadors, other public Ministers and Consuls, and those in which a State shall be Party, the Supreme Court shall have original Jurisdiction.").

32. See KAHN, supra note 4, at 4 (observing that "Marbury's world has become a common world for most of us, most of the timc"); Monaghan, supra note 4, at 8 (terming Marbury "our most important decision").

33. See, e.g., BICKEL, supra note 5, at 74; KAHN, supra note 4, at 4.

34. See, e.g., Coll. Sav. Bank v. Fla. Prepaid Postsecondary Educ. Expense Bd., 527 U.S. 666, 688 (1999) (noting that "debate over whether Marbury v. Madison ... was wrongly decided" has been consigned by tradition and experience "to forums more other-worldly than ours"). But cf. Myers v. United States, 272 U.S. 52 (1926) (disapproving of Marbury's holding that Congress can prescribe the terms of office and conditions for presidential removal of executive officials). 
constitutional lawyers must understand Marbury, or interpret it, or make sense of its implications. To understand Marbury is to understand the practice of constitutional law, or at least the judicial role; ${ }^{35}$ and to understand our constitutional practice is to understand Marbury. The two are too much interconnected in the constitutional mind for a perception of one not to color, or indeed sometimes determine, an understanding of the other. As Paul Kahn has written, "The study of constitutional law not only begins with this case, it ends there as well," in debates about judicial review and the appropriate judicial role. ${ }^{36}$

\section{II \\ MARBURY'S THREE FACES}

Marbury can exert its extraordinary hold on the constitutional mind in part because of its remarkable, multifaceted richness. More particularly, John Marshall's canonical opinion includes at least three facets or faces. It could plausibly be claimed that any of these reflects an essential element of Marshall's reasoning and expresses the foundational insights that subsequent judicial praetice must follow in order to be true to Marbury. In later Sections of this Article, I shall discuss the tensions among Marbury's three faces and consider whethcr those tensions lapse into contradiction. For now, I mean only to emphasize the rich, textured, multifaceted character of Marbury and to suggest how Marbury's three faces help to support an equally rich, textured, and multifaceted, but also tension-ridden, constitutional practice.

\section{A. The Three Faces Emerging from Marbury's Reasoning}

Marbury's divergent faces emerge partly from a parsing of the Court's opinion, as refracted through subsequent argumentation and judicial practice, and partly from attention to the surrounding political context.

\section{The Private-Rights Face}

Judicial review gives federal judges, who are not directly accountable to the electorate, a power that is potentially threatening to more representative branches of government and to political democraey. ${ }^{37}$ Marbury's private-rights face rcsponds directly to this threat and attempts to disarm it. This face represents Marbury as a species of traditional private litigation. It

35. See Erwin Chemerinsky, Federal Jurisdiction 13 (3d ed. 1999) ("John Marshall . . u used the occasion of deciding Marbury... to articulate a role for the federal courts that survives to this day.").

36. KAHN, supra note 4, at 4.

37. For a classic statement of this concern, see James Bradley Thayer, The Origin and Scope of the American Doctrine of Constitutional Law, 7 HaRv. L. Rev. 129 (1893). 
casts the Justices of the Supreme Court as ordinary judges humbly doing their best to apply the law to disputes between individuals. ${ }^{38}$

In Marbury, the Justices claimed no general authority to resolve constitutional issues that might arise in American politics ${ }^{39}$ Rather, Marshall's reasoning grounds the Court's exercise of judicial review in its need to decide the case before it, which involved Marbury's claimed right to judicial relief under the law of the United States. ${ }^{40}$ To adjudicate Marbury's claim, the Court necessarily had to consider all applicable law, including the Constitution as the supreme law. ${ }^{41}$ In adopting the Constitution of the United States, "the People" had worked an innovation by establishing legal norms with which ordinary legislation might conflict. ${ }^{42}$ But this face of Marbury denies that the people had otherwise altered the judicial role. That role remained one of simply ascertaining the applicable law as necessary to resolve otherwise traditional cases involving one party's claims of right against another. ${ }^{43}$

Marbury's private-rights face suffuses and inspires what has been called "the private rights model" of constitutional adjudication. ${ }^{44}$ Within this model, courts have no warrant to decide constitutional issues except as necessary to adjudicate a concrete dispute. ${ }^{45}$ As Marshall asserted, "The province of the court is, solely, to decide on the rights of individuals." ${ }^{.46}$ The private-rights model also generates a symmetrical obligation: When a constitutional issue arises within a traditionally framed case and is necessary to the determination of private rights, courts have no discretion to

38. See Monaghan, supra note 4, at 12 ("Marshall simply extrapolates the judicial role in constitutional cases from the 'ordinary and humble judicial duty' in conventional cases." (quoting Thayer, supra note 37 , at 138)).

39. See Marbury v. Madison, 5 U.S. (1 Cranch) 137, 170 (1803) ("The province of the eourt is, solely, to decide on the rights of individuals ....").

40. See Charles Alan Wright \& Mary Kay Kane, Law of Federal Courts 62 (6th ed. 2002) ("In Marbury v. Madison it was central to Chief Justice Marshall's argument that a court has power to declare a statute uneonstitutional only as a consequence of the power of the eourt to decide a case properly before it.") (footnote omitted).

41. See Marbury, 5 U.S. at 178 (noting that if both the Constitution and a purported law in violation of the Constitution "apply to a particular case, ... the court must determine which of these conflicting rules governs the case").

42. See id. at 176 (noting that "the people" had exereised an "original right" to establish the Constitution as "fundamental" law).

43. See id. at 170 (concluding that Secretary of State Madison's position could not "exempt him from this particular mode of deciding on the legality of his conduct, if the case be such a case as would, were any other individual the party complained of, authorize the process").

44. See FALLON ET AL,, supra note 5, at 78-79; Henry P. Monaghan, Constitutional Adjudication: The Who and When, 82 Y ALE L.J. 1363, 1365-66 (1973) (outlining the private-rights model and tracing it to Marbury).

45. See Marbury, 5 U.S. at 170; Monaghan, supra note 44, at 1366 (observing that "Marbury's analogy of constitutional litigation to 'ordinary' common law litigation strongly suggested that the occasions for judicial review were limited to the protection of identifiable and concrete personal rights").

46. Marbury, 5 U.S. at 170. 
avoid the issue or to decline to enforce constitutional rights. ${ }^{47}$ Marshall famously intoned in Marbury that for every right there must be a remedy and that, if this were not so, the governmental framework would cease to be one of laws and not of men. ${ }^{48}$

\section{The Special-Functions Face}

In justifying the Court's exercise of judicial review, Marbury asserted that "it is emphatically the province and duty of the judicial department to say what the law is." ${ }^{49}$ The force of this proposition can be seen as conditioned by the case's facts, involving a concrete and traditional claim of individual right, ${ }^{50}$ but acceptance of this limit is not strictly necessary. ${ }^{51}$ The grounds for a broader view lie in Marbury's expressly functional argument: If other branches of government, especially Congress, could exceed constitutional bounds without being subject to judicial check, then the restraining function of a written constitution would be obliterated. ${ }^{52}$

Marbury's argument on this point is not wholly complete. Without further elaboration, Marshall's reasoning invites a symmetrical objection: Judicial review, which implies judicial finality, merely substitutes the Supreme Court for Congress as the institution permitted to overstep its constitutional powers. ${ }^{53}$ Attempting to fill the argumentative gap, champions of judicial review have maintained that a life-tenured Supreme Court, thus freed from the pressures of partisan politics, has a special capacity that political officials typically do not possess for conducting a long-sighted, disinterested analysis of constitutional issues. ${ }^{54}$ If the premise is granted

47. See Richard S. Kay, Constitutional Cultures, Constitutional Law, 57 U. CHI. L. Rev. 311 , 323 (1990). Kay asserts that

a corollary to Marshall's holding in Marbury that the Constitution is enforceable law is his dictum in Cohens v. Virginia [19 U.S. (6 Wheat.) 264, 404 (1821)] on the duty of courts to adjudicate: ... "We have no more right to decline the exercise of a jurisdiction which is given, than to usurp that which is not given. The one or the other would be treason to the Constitution."

Id.

48. Marbury, 5 U.S. at 163.

49. Id. at 177 .

50. Indeed, the very next sentence in Marshall's opinion can be read to link the judiciary's lawdeclaring powers to the necessity of deciding cases: "Those who apply the rule to particular cases, must of necessity expound and interpret that rule." $I d$. at 177 .

51. See, e.g., David P. CURRIE, Federal CourTs 7-8 (4th ed. 1990) (noting that certain passages in Marbury "suggest that Marshall viewed judicial review" not as "an incidental consequence of the courts' basic job of deciding particular cases," but "as an instrument for keeping the Congress within constitutional bounds, a vital element in the system of checks and balances"); Monaghan, supra note 44, at 1370 (noting the potentially broader implications of Marshall's premises).

52. See Marbury, 5 U.S. at 178 (asserting that if judicial review were not contemplated, the Constitution "would be giving to the legislature a practical and real omnipotence, with the same breath which professes to restrict their powers within narrow limits").

53. See BiCKel, supra note 5, at 3-4.

54. See, e.g., id. at 25 (asserting that "courts have certain capacities for dealing with matters of principle that legislatures and executives do not possess"); MCCLOSKEY, supra note 19, at 229 (terming 
that the Court has a special and needed capacity to render long-sighted constitutional judgments, the constraints imposed by the private-rights model may look ill designed. According to what has been called a "special functions" or "public rights" model ${ }^{55}$ the courts should provide safeguards against constitutional violations by other branches, even in cases that do not involve the kinds of private rights and material injuries that typically underlie suits at common law. This model holds that there is a public interest, appropriately enforced through public-rights litigation, in ensuring official conformity to legal and especially constitutional norms. ${ }^{56}$ Champions of a special-functions approach have also asserted a related claim that the articulation of constitutional norms is a general public good, partly independent of the need to remedy particular wrongdoing. ${ }^{57}$

At least with the benefit of hindsight, it is easy to trace the specialfunetions model to Marbury. ${ }^{58}$ As Henry Monaghan has noted, Marbury

the judiciary "the one governmental element disposed by its nature to take the long run into account"). According to McCloskey, "An impulsive nation like ours, much given to short-run fads, enthusiasms and rages, can little afford to dispense with the one governmental element that is disposed by its nature to take the long-run into account." MCCLOSKEY, supra note 19, at 228-29.

55. See Monaghan, supra note 44, at 1371-75 (defining the model); see also FALLON ET AL., supra note 5, at 79-80 (citing Monaghan, among others, in identifying a "public rights" or specialfunctions model contrasting with a "dispute resolution" or "private rights" model).

56. "[A]t least three ... historical phenomena have contributed to the emergence" of the specialfunctions or public-rights model:

The first involves the vast increase in governmental rcgulation, especially when administered by administrative agencies, that has created diffuse rights shared by large groups and new legal relationships that are hard to capture in traditional, private law terms.... A second factor... has been the substantive expansion of constitutional rights, especially under the Warren Court in the 1960 s. For example, the broadly shared interests of voters in challenging a malapportioned legislative district, see Baker v. Carr, 369 U.S. 186 (1962), . . or of public school pupils in challenging school prayer, see School Dist. v. Schempp, 374 U.S. 203 (1963), differ markedly from the liberty and economic interests recognized at common law.... Third, therc has emerged an increasingly pervasive conception of constitutional rights not as shields against governmental coercion, but as swords authorizing the award of affirmative relief to redress injury to constitutionally protected interests.

Fallon eT AL., supra note 5, at 80-81.

57. For a celebration of this approach and an assertion of its primacy, see Owen Fiss, The Forms of Justice, 93 Harv. L. Rev. 1, 30 (1979) (asserting that "the function of the judge-a statement of the social purpose and a definition of role-is not to resolve disputes, but to give the proper meaning to our public values"). See also Susan Bandes, The Idea of a Case, 42 Stan. L. Rev. 227, 281-92 (1990) (arguing that federal courts should identify justiciable eases in awareness of the public benefits of judieial interpretation and enforcement of the Constitution); Abram Chayes, The Role of the Judge in Public Law Litigation, 89 HARv. L. Rev. 1281 (1976) (noting ways in which public law litigation frequently departs from the traditional private law model and assessing the appropriate judicial role in public actions).

58. For an explicit statement of the linkage, see Cooper v. Aaron, 358 U.S. 1, 17-19 (1958), in which the Court famously asserted that under Marbury, prineiples once enunciated by the Supreme Court were binding on all publie officials, including those not party to the case triggering the Court's pronouncement:

Article VI of the Constitution makcs the Constitution the "supreme Law of the Land." In 1803, Chief Justice Marshall, speaking for a unanimous Court, referring to the Constitution as "the fundamental and paramount law of the nation," declared in the notable case of Marbury v. Madison, 1 Cranch 137, 177, that "It is emphatically the province and duty of the judicial department to say what the law is." This decision declared the basic principle that the federal 
"weld[s] judicial review to the political axiom of limited government" and thereby "provides the basis" for a special-functions approach. ${ }^{59}$ What is more, important strands in Marbury appear to reject the insistence of the private-rights model that constitutional issues should be decided only as strictly necessary. In pronouncements that turned out to be quite unnecessary in view of the ultimate dismissal of the case on jurisdictional grounds, Marshall began by concluding generally that for every right, there must be a remedy ${ }^{60}$ and that the courts, in furnishing legally appropriate remedies, may compel the performance of legal duties by high governmental officials including the secretary of state ${ }^{61}$ These pronouncements reflect Marbury's special-functions face. ${ }^{62}$

\section{The Political or Prudential Face}

Marbury's third face becomes visible when one looks beneath the Court's rhetoric and considers the decision in its political context. This is a

judiciary is supreme in the exposition of the law of the Constitution, and that principle has ever since been respected by this Court and the Country as a permanent and indispensable feature of our constitutional system. It follows that the interpretation of the Fourteenth Amendment enunciated by this Court in the Brown case is the supreme law of the land, and Art. VI of the Constitution makes it of binding effect on the States "any Thing in the Constitution or Laws of any State to the Contrary notwithstanding." Every state legislator and executive and judicial officer is solemnly committed by oath taken pursuant to Art. VI, cl. 3, "to support this Constitution."

Id. at 18.

59. Monaghan, supra note 44 , at 1370.

60. Marbury v. Madison, 5 U.S. (1 Cranch) 137, 163 (1803).

61. Id. at 169-73. William Van Alstyne, A Critical Guide to Marbury v. Madison, 1969 DUKE L.J. 1, 6-8 (1969), advances an ingenious but ultimately unpersuasive defense of Marshall's approach that is consistent with the private-rights model. According to Van Alstyne, a determination either that Marbury had no right to a remedy or that mandamus could not issue against the Secretary of State would have enabled the Court to avoid the constitutional question whether Section 13 of the 1789 Judiciary Act effected a valid grant of original Supreme Court jurisdiction. As Van Alstyne recognizes, however, in the absence of jurisdiction the Court would have no authority to decide issues unrelated to the determination of its own jurisdiction. See id. at 7; see also Steel Co. v. Citizens for a Better Env't, 523 U.S. 83, 10I (1998) (holding that courts must decide jurisdictional issues at the outset and that pronouncements on other issues in the absence of jurisdiction would produce "nothing more than a hypothetical judgment-which comes to the same thing as an advisory opinion"). According to Van Alstyne, the question whether Marbury had a right to his commission, as an aspect of the question whether Marbury had a claim for which Madison could be answerable in court in his official capacity, is "an issue respecting "jurisdiction." Van Alstyne, supra at 8. But this is a bridge too far; it wholly obliteratcs the distinction between jurisdictional and merits issues in every case involving a claim that the defendant is not amenable to suit, either generally or on the facts of the case.

62. See Desist v. United States, 394 U.S. 244, 256 (1969) (Douglas, J., dissenting) (observing that the "tradition" of "producing only dictum through a "case or controversy'... started with Marbury"); Webster v. Reprod. Health Servs., 492 U.S. 490 (1992) (Scalia, J., concurring). Justice Scalia stated:

I havc not identified with certainty the first instance of our deciding a case on broader constitutional grounds than absolutely necessary, but it is assuredly no later than Marbury $v$. Madison, where we held that mandamus could constitutionally issue against the Secretary of State, although that was unnecessary given our holding that the law authorizing the issuance of mandamus by this court was unconstitutional.

Id. at 533 (citation omitted). 
political face of judicial prudence tinctured with guile. Its central prescription is that the Court must sometimes recede from conflict with the political branches or with aroused public opinion in order to maintain its prestige and thus its power:

As the facts surrounding Marbury illustrate, the authority of the Supreme Court is not self-enforcing. To sustain and legitimate its place in a constitutional democracy, the Court must define for itself a democratically acceptable role. The sources of the Court's vulnerability are several. First, the Court's orders are not self-executing. Unless the Court maintains public esteem, outright defiance by political officials is by no means unthinkable. Thomas Jefferson and James Madison seemed poised to ignore the Supreme Court's writ of mandamus if one had issued in Marbury.$^{63}$ If a pattern of defiance developed, the Court would be relegated to the margins of constitutional significance. Second, Article III vests Congress with express power to control and limit the appellate jurisdiction of the Supreme Court. ${ }^{64}$ Although the constitutional boundaries of this power are largely untested, ${ }^{65}$ the scope is probably broad enough for the political branches to rebuff the Court and undermine its stature. ${ }^{66}$ Third, the political branches possess constitutional authority not only to determine the membership of the Supreme Court through appointment and confirmation processes, but also to adjust its size. ${ }^{67}$ In conjunction, these powers make "Court packing"

63. See supra text accompanying notes 24-25. The threat in Marbury was not unique to its time. Roughly sixty years later, Abraham Lincoln ordered military officials to defy a writ of habeas corpus issued during the Civil War in Ex parte Merryman. 17 F. Cas. 144 (1861). For discussions of Merryman and its eontext, see James Garfield Randall, Constitutional Problems Under LinColn 118-68 (rev. ed. 1951); William H. Rehnquist, All the Laws But One: Civil Liberties IN WARTIME (1998).

64. U.S. ConST. art. III, $\S 2$, cl. 2 (providing that the Supreme Court's appellate jurisdiction shall be subjeet to "sueh Exceptions, and under such Regulations as the Congress shall make").

65. See FALLON ET AL., supra note 5, at 365-70 (exploring a variety of issues involving congressional power over the Court's appellate jurisdiction).

66. In perhaps the most celebrated effort to define limits on Congress's power, Henry Hart argued that any limitations must not be of a kind that would "destroy the essential role of the Supreme Court in the constitutional plan." Henry M. Hart, Jr., The Power of Congress to Limit the Jurisdiction of Federal Courts: An Exercise in Dialectic, 66 HARv. L. Rev. 1362, 1364-65 (1953); see also Leonard G. Ratner, Congressional Power Over the Appellate Jurisdiction of the Supreme Court, 109 U. PA. L. REv. 157 (1960) (attempting to specify essential Supreme Court functions limiting Congress's power to withdraw jurisdiction). Akhil Amar has argued that the Constitution requires that some federal court should have jurisdiction over important classes of eases, including all cases arising under the Constitution and laws of the United States, but would permit the withdrawal of Supreme Court appellate jurisdiction as long as jurisdiction remained in the lower federal eourts. See Akhil Reed Amar, The Two-Tiered Structure of the Judiciary Act of 1789, 138 U. PA. L. REv. 1499 (1990); Akhil Reed Amar, A Neo-Federalist View of Article 111: Separating the Two Tiers of Federal Jurisdiction, 85 B.U. L. REv. 205 (1985). Others, however, have argued that Congress's power to restriet the Supreme Court's appellate jurisdietion is essentially unlimited. See, e.g., Herbert Wechsler, The Courts and the Constitution, 65 Colum. L. Rev. 1001, 1005-06 (1965).

67. The Constitution does not speeify the size of the Supreme Court. After the first judiciary act provided that the Court would have six members, see FALLON ET AL., supra note 5, at 28, the number 
at least a potential response to judicial decisions that aroused political majorities adjudge intolerable. ${ }^{68}$

In Marbury, the Court reached the only prudent conclusion: It could not, indeed must not, issue a quixotic order to Madison to deliver Marbury's commission. But never before or since has the Court, in prudent retreat, displayed more guile to emerge in glory from the specter of defeat. In the judgment of many, Marshall was able to conclude that the 1789 Judiciary Act attempted an unconstitutional conferral of original jurisdiction on the Supreme Court only by plainly, possibly willfully, misinterpreting the statute. ${ }^{69}$ The purported conferral of original Supreme Court jurisdiction in mandamus actions came in a sentence of the 1789 Judiciary Act that began by conferring appellate jurisdiction on the Supreme Court and then granting the authority to issue writs of mandamus. ${ }^{70}$ The natural reading would be that the Court could issue writs of mandamus in cases properly before it, typically in the exercise of its appellate jurisdiction, where such writs were necessary to effectuate its decisions. ${ }^{71}$ Marshall, however, found that Congress had made a free-standing grant of original jurisdiction in mandamus actions. He did so despite-or perhaps because of-constitutional language providing for original Supreme Court

of Justices reached a high of ten in 1863 , before being reduced briefly to seven and then settling at the current nine in 1869. See id. at 35.

68. See generally William E. Leuchtenburg, The Supreme Court Reborn: The Constitutional Revolution in the Age of Roosevelt (1995) (discussing President Franklin Roosevelt's failed Court-packing effort and its long-run significance).

69. See, e.g., Akhil Reed Amar, Marbury, Section 13, and the Original Jurisdiction of the Supreme Court, 56 U. CHI. L. REv. 443, 456 (1989) (concluding that Marshall misinterpreted the statutory provision that he subsequently found to be unconstitutional as so interpreted); David Currie, The Constitution in Congress: Substantive Issues in the First Congress, 1789-1791, 61 U. CHI. L. Rev. 775,865 n.507 (1994) (same). But see Jamcs Pfander, Marbury, Original Jurisdiction, and the Supreme Court's Supervisory Powers, 101 COLUM. L. REv. 1515 (2001) (concluding that Marshall's statutory conclusion was well founded). For further discussion of Pfander's revisionist thesis, see infra notes 240-47 and accompanying text.

70. Act of Sept. $24,1789,1$ Stat. $73, \S 13$ (1845), provides:

The Supreme Court shall also have appellate jurisdiction from the circuit courts and courts of the several states, in the cases herein after provided for; and shall have power to issue writs of prohibition to the district courts, when proceeding as courts of admiralty and maritime jurisdiction, and writs of mandamus, in cases warranted by the principles and usages of law, to any courts appointed, or persons holding office, under the authority of the United States.

1d. From this sentence, Marshall quoted only the final fragment referring to writs of mandamus. See Marbury v. Madison, 5 U.S. (1 Cranch) 137, 173 (1803).

The quoted language comes from the 1845 version of the Statutes at Large. Although commentators have generally assumed that this was the language on which Marshall relied, James Pfander argues that Marshall was more likely to have consulted a 1796 edition of the officially authorized, but privately published, Laws of the United States, which substituted a colon for the semicolon in the quoted sentence and capitalized the "And" that immediately follows it. Pfander, supra note 69, at 1535-39. According to Pfander, the text of the privately published 1796 edition supports a revisionist conclusion that Congress actually intended to vest the Court with a "freestanding" mandamus jurisdiction. See id.

71. See Amar, supra note 69 , at 456 . 
jurisdiction in a small category of cases, ${ }^{72}$ not including mandamus actions, and asserting that "in all other cases" the Court "shall exercise appellate jurisdiction." ${ }^{\text {"73 }}$ Marshall's broad interpretation of the statute enabled him to hold the statute unconstitutional, thereby establishing the precedent of judicial review, even as he avoided a collision with the Jefferson administration by denying Marbury any relief.

In standard renditions, Marshall's political motivations and wiliness dominate the analysis of Marbury v. Madison and illuminate its political or prudential face. ${ }^{74}$ The core insight is that the Court must sometimes avoid conflicts that might subject it to rebuff or retaliation. ${ }^{75}$ Other prescriptions may also emerge from this face, depending on how broadly Marbury's prudential rationale is understood. Even if the face of prudence is typically one of judicial self-abnegation, there may be occasions when prudence counsels an otherwise constitutionally dubious assertion of judicial power. In Marbury itself, for example, the Court arguably invented a nonexistent statutory jurisdiction in order to be able to hold, at least debatably, that Congress had overstepped constitutional bounds. ${ }^{76}$

72. See U.S. CoNST. art 111, § 2, cl. 2 ("In all Cases affecting Ambassadors, other public Ministers and Consuls, and those in which a States shall be a Party, the supreme Court shall have original Jurisdiction.").

73. Id.

74. See, e.g., McCloskey, supra note 19, at 40 ("The decision is a masterwork of indirection, a brilliant example of Marshall's capacity to sidestep danger while seeming to court it, to advance on one direction while his opponents are looking in another."); Amar, supra note 69, at 462 ("In the middle of a political minefield ... John Marshall managed to empower his branch even as he backed away from a fight with a new and popular President."); see also Pfander, supra note 69, at 1515-18 (summarizing authorities that reached the conclusion that Marshall's decision was politically motivated). But see Robert Lowry Clinton, MaRBURY v. Madison and Judicial Review 79-138 (1989) (arguing that Marshall's Marbury opinion was essentially innocent of political motivation).

75. See, e.g., MCCLoskey, supra note 19, at 229-31 (arguing that "the Court's greatest successes have been achieved when it has operated near the margins rather than at the center of political controversy" and that "[i]t would be a pity if the judges, having done so much, should now once more forget the limits that their own history so compellingly prescribes").

According to Mark Graber, Marshall's canonical opinion in Cohens v. Virginia, 19 U.S. (6 Wheat) 264 (1821), also followed a shrewdly prudential approach, analogous to that apparently adopted in Marbury: Marshall made palatable an assertion of Supreme Court authority to review state criminal decisions, despite objections founded on the Eleventh Amendment, by reaching the implausible conclusion that the state conviction at issue did not violate federal law. Mark A. Graber, The PassiveAggressive Virtues: Cohens v. Virginia and the Problematic Establishment of Judicial Power, 12 Const. Comment. 67 (1995); see also R. Kent Newmyer, John Marshall, McCulloch v. Maryland, and the Southern States' Rights Tradition, 33 J. Marshall L. Rev. 875 (2000) (discussing Marshall's response to hostility to Supreme Court authority).

76. See Van Alstyne, supra note 61, at 31 (observing that the constitutional reference to cases in which the Supreme Court would have original jurisdiction might have been interpreted as specifying an irreducible minimum, not a maximum). But see Amar, supra note 69, at 463-78 (arguing that Marbury was correct in reading Article $11 \mathrm{I}$ as establishing specific limits on the Supreme Court's appellate jurisdiction). 
Cases in which the Court has failed for arguably prudential reasons to enforce individual rights often occasion regret. ${ }^{77}$ By contrast, Marbury is almost invariably viewed as a judicial triumph. ${ }^{78}$ The case's political and prudential face is thus perhaps the best possible face to represent the school of constitutional thought that emphasizes the need for judicial prudence. Vivid illustration comes from a recent article by Laurence Tribe, in which he imagines how disastrous the result might have been had Marbury been decided by a Court displaying the brazen arrogance that he ascribes to the current Court. ${ }^{79}$ Tribe's imagined scenario ends with the Court's conclusion that " $[\mathrm{h}]$ ence the writ shall issue'-at which point all hell breaks loose, Jefferson tells Madison to defy the Court, Marshall and several colleagues are impeached and convicted, and the next 200 years look entirely different." $\$ 80$

\section{B. The Continuing Influence of the Three Faces in Modern Constitutional Practice}

At least in the eyes of some, each of Marbury's faces holds an essential moral, political, or functional truth about judicial review. Moreover, although the faces point in different directions, each is reflected in contemporary doctrine and practice.

\section{The Influence of the Private-Rights Face}

To reject the minimal demand of Marbury's private-rights face-that courts must vindicate private rights whenever called upon to do so in order to resolve concrete disputes-would be to compromise an ideal that has seemed almost self-evidently correct to many, if not most, American constitutionalists. This is the vision that inspires Henry Hart's magisterial Dialogue ${ }^{81}$ which continues to be the most acclaimed and forceful scholarly statement of the necessary role of courts in the constitutional

77. See, e.g., MCCLOSKEY, supra note 19, at 201 (criticizing Supreme Court decisions upholding the forced relocation of Japanese Americans during World War 11); Michael J. Perry, The Constitution in the Courts: Law or Politics 145 (1994) (characterizing Plessy v. Ferguson, 163 U.S. 537 (1896), which upheld race-based segregation, as "ridiculous and shameful").

78. See, e.g., Chemerinsky, supra note 35, at 13 ("The brilliance of John Marshall's opinion cannot bc overstated.").

79. See Laurence H. Tribe, Erog v. Hsub and Its Disguises: Freeing Bush v. Gore from Its, Hall of Mirrors, 115 HaRv. L. REv. 170, 303 (2001).

80. Id. Explicitly assuming that the Court should sometimes act with the prudential sensibility that he identifies with Marbury, Tribe continues:

What the Court needs now is not a curtailment of the power that Marbury established, but a return to the contextual sclf-awareness that Marbury displayed. How much and when the Court should decide depends on the constitutional principle to be vindicated, the political controversy in which a controversy is embedded, and the social, cultural, and historical sources at play.

Id. at 304.

81. See Hart, supra notc 66. 
scheme: Where courts sit, the demands of law and constitutional rights must prevail. ${ }^{82}$ The proposition that it is the core judicial duty to enforce the rights of individuals echoes equally strongly in the work of contemporary liberals such as Ronald Dworkin. ${ }^{83}$

At the level of doctrine, I know of no case in which a court has claimed that courts have a general discretion simply to decline to enforce an otherwise justiciable and valid claim of legal right. ${ }^{84}$ Under a few "abstention" doctrines the Supreme Court has asserted a discretion to require that a claim of right should be adjudicated in the first instance in a state, rather than a federal, court ${ }^{85}$ Legal doctrine also acknowledges significant judicial discretion in the award of equitable remedies, which traditionally were not available as of right. ${ }^{86} \mathrm{But}$ the abstention doctrines, which are themselves controversial, ${ }^{87}$ speak only to the duties of federal courts in cases in which they enjoy concurrent jurisdiction with state courts, not to the obligations of the nation's judiciary as a whole. Even when abstention doctrines are taken into account, the Supreme Court refers regularly to the federal courts' "virtually unflagging obligation" to exercise the jurisdiction conferred by Congress. ${ }^{88}$

82. See id. at 1393 (asserting that "the Constitution always applies when a court is sitting with jurisdiction in habeas corpus" and that "the court has always to inquire... whether the petitioner before it has been 'deprived of life, liberty, or property, without due process of law"'). This was also the view of Hart's great collaborator. See Herbert Wechsler, The Courts and the Constitution, 65 Colum. L. Rev. 1001, 1006 (1965) (asscrting that under Marbury, courts must decide cascs within their jurisdiction in order to "give effect to the supreme law of the land").

83. See, e.g., Dworkin, supra note 10, at xi (asserting that "[i]ndividual rights are political trumps held by individuals").

84. Admittedly, this claim is carefully formulated. As the remainder of this paragraph suggests, although courts have no "general discretion" to decline to enforce rights, a number of justiciability, immunity, and remedial doctrines create circumstances under which there is no available judicial remedy for legal and constitutional rights, notwithstanding Marbury's famous dictum to the contrary. See Richard H. Fallon, Jr. \& Daniel J. Meltzer, New Law, Non-Retroactivity, and Constitutional Remedies, 104 HARV. L. REv. 1731, 1779-86 (1991) (describing departures from the maxim that for every right there must be a remedy).

85. See, e.g., Younger v. Harris, 401 U.S. 37 (1971) (cstablishing the Younger doctrine under which federal courts will characteristically abstain from enjoining pending state judicial proceedings brought by state officials to enforce state law or othcrwise implicating important state interests); Railroad Comm'n of Texas v. Pullman Co., 312 U.S. 496 (1941) (initiating the Pullman doctrine under whieh fcderal courts will sometimes abstain from deciding cases presenting fcderal constitutional questions pending state court resolution of difficult state law issues that might moot or alter the constitutional issue). See generally FALLON ET AL., supra note 5, at 1222-1336 (discussing federal abstention doctrines).

86. See generally Douglas Laycock, Modern American Remedies 229-344 (2d ed. 1994) (discussing principles governing availability of equitable remedies).

87. For a spirited attack, sce Martin H. Redish, The Federal Courts in the Political Order: Judicial Jurisdiction and American Political Theory 47-74 (1991). For a thoughtful defense, see David L. Shapiro, Jurisdiction and Discretion, 60 N.Y.U. L. Rev. 543, 545 (1985) (maintaining that claims of a virtually exceptionless obligation to exercise jurisdiction "are far too grudging in their recognition of judicial discretion in matters of jurisdiction").

88. See, e.g., Quackenbush v. Allstate Ins. Co., 517 U.S. 706, 716 (1996) (quoting Colorado River Water Conservation Dist. v. United States, 424 U.S. 800, 821 (1976)); Wilton v. Seven Falls Co., 
Although Marbury's private-rights face is perhaps most forceful in identifying the courts' minimal duty, its justification of the judicial role by reference to the imperative of vindicating concrete rights also highlights the hazards of a broader judicial function. If courts attempt to do more, they invite objections that they have trenched on domains more properly reserved for political judgment. ${ }^{89}$

In post-Marbury decisions, the principle that courts should engage in constitutional adjudication only to protect the concrete rights of identified individuals finds abundant expression. Standing doctrine affords one prominent example..$^{90}$ The Supreme Court has asserted recurrently that federal courts may not exercise jurisdiction at all in the absence of a "distinct and palpable" injury to particular individuals." This limitation, the Court has stated, is "founded in concern about the proper-and properly limited-role of the courts in a democratic society." 92 The doctrine of constitutional avoidance ${ }^{93}$ furnishes another example of judicial

515 U.S. 277, 283 (1995) (also quoting Colorado River Water Conservation Dist., 424 U.S. at 813, 817-18); see also England v. La. Bd. of Med. Exam'rs, 375 U.S. 411, 415 (1964) ("When a federal court is properly appealed to in a case over which it has by law jurisdiction, it is its duty to take such jurisdiction."); Cohens v. Virginia, 19 U.S. (6 Wheat.) 264, 404 (1821) (Marshall, C.J.) ("We have no more right to dccline the exercisc of a jurisdiction which is given, than to usurp that which is not given. The onc or the other would bc treason to the Constitution."). See generally James Rehnquist, Taking Comity Seriously: How to Neutralize the Abstention Doctrine, 46 STAN. L. Rev. 1049, $1102-05$ (1994) (arguing that the Cohens dictum is reconcilable with abstcntion doctrines).

89. See Raines v. Byrd, 521 U.S. 811, 828-29 (1997) (quoting United States v. Richardson, 418 U.S. 166, 192 (1974) (Powell, J., concurring) (asserting that it is the judicial role in protecting concrete minority rights, "not some amorphous general supervision of the operations of government, that has maintained public esteem for the federal courts and has permitted the peaceful coexistence of the countermajoritarian implications of judicial rcvicw and the democratic principles upon which our Federal Government in the final analysis rests")).

90. See Lujan v. Defenders of Wildlife, 504 U.S. 555, 576 (1992) (citing Marbury's assertion that "[t]he province of the court ... is, solely, to decide on the rights of individuals" as authority for denying congressional authority to authorize citizen suits to vindicate the public interest); Valley Forge Christian Coll. v. Ams. United for Separation of Church \& State, 454 U.S. 464, 473-74 (1982) (asserting that since Marbury, judicial review has been exercised only as "a tool of last resort" where necessary to protect only those litigants who can demonstrate "injury in fact"); see also Antonin Scalia, The Doctrine of Standing as an Essential Element of the Separation of Powers, 17 SUFFoLK U. L. REv. 881,894 (1983).

The law of standing roughly restricts courts to their traditional undemocratic role of protecting individuals and minorities against impositions of the majority, and excludes them from the even more undemocratic role of prescribing how the othcr two branches should function in order to serve the intcrest of the majority itself.

ld.

91. See, e.g., Allen v. Wright, 468 U.S. 737, 751 (1984) (quoting Gladstone, Realtors v. Vill. of Bellwood, 441 U.S. 91, 100 (1979) (quoting Warth v. Seldin, 422 U.S. 490, 501 (1975))).

92. Warth v. Seldin, 422 U.S. 490,498 (1975).

93. The classic articulation of the desirability of avoiding constitutional decisions is Justice Brandeis's concurring opinion in Ashwander v. Tennessee Valley Authority, 297 U.S. 288, 346 (1936), which outlined seven numbcred rules under which the Court avoids "passing upon a large part of all the constitutional questions pressed upon it for decision." According to Gerald Gunther, three of Brandeis's avoidance rules involve justiciability doctrines defining "situations in which there is no 'case' or 'controversy' in terms of the jurisdictional content of Article 11l" and no clcment of judicial choice 
self-limitation that reflects Marbury's private-rights face, which justifies constitutional adjudication only insofar as it is necessary "to decide on the rights of individuals." ${ }^{.94}$ In one of its aspects, the avoidance doctrine prescribes that courts will resolve constitutional issues only as a matter of last resort and strict necessity. ${ }^{95}$ For example, when a party seeking relief on constitutional grounds also asserts a claim under a federal statute or regulations, the Court almost invariably decides the nonconstitutional issues first. ${ }^{96}$ Another frequently cited prescription of constitutional avoidance calls for courts to prefer statutory interpretations that do not generate constitutional difficulties: "[W]here an otherwise acceptable construction of a statute would raise serious constitutional problems, the Court will construe the statute to avoid such problems unless such eonstruction is plainly contrary to the intent of Congress." 97

\section{The Influence of the Special-Functions Face}

Myriad aspects of the current legal structure are difficult, if not impossible, to rationalize except in light of Marbury's special-functions face. $^{98}$ The statutory structure governing Supreme Court review of lower

therefore enters the picture. Gerald Gunther, The Subtle Vices of the "Passive Virtues"-A Comment on Principle and Expediency in Judicial Review, 64 Colum. L. Rev, 1, 17 (1964). Gunther also emphasizes that the other four involve "avoidance only of some or all of the constitutional questions argued, not avoidance of all decision on the merits ...." Id. at 16.

94. Marbury v. Madison, 5 U.S. (1 Cranch) 137, 170 (1803); see also Cohens v. Virginia, 19 U.S. (6 Wheat.) 264, 441 (1821) (Marshall, C.J.) (asserting that where a case can be resolved on statutory grounds, "it will be unnecessary, and consequently improper, to pursue any inquiries, which would then be merely speculative, respecting the power of congress in the case").

95. See, e.g., Dep't of Commerce v. United States House of Representatives, 525 U.S. 316, 343 (1999) ("If there is one doctrine more decply rooted than any other in the process of constitutional adjudication, it is that we ought not to pass on questions of constitutionality... unless such adjudication is unavoidable.") (quoting Spector Motor Serv. v. McLaughlin, 323 U.S. 101, 105 (1944)).

96. See, e.g., id:; United States v. Locke, 471 U.S. 84, 93 (1985). See generally Lisa A. Kloppenberg, Avoiding Constitutional Questions, 35 B.C. L. Rev. 1003 (1994) (describing this as the "last resort rule").

97. Edward J. DeBartolo Corp. v. Fla. Gulf Coast Bldg. \& Constr. Trades Council, 485 U.S. 568, 575 (1988). The canon that courts should construe statutes to avoid constitutional difficulties has recently attractcd criticism. See, e.g., Richard Posner, Statutory Interpretation-In the Classroom and in the Courtroom, 50 U. CHI. L. REv. 800, 816 (1983) (arguing that "[t]he practical effect of interpreting statutes to avoid raising constitutional questions is ... to enlarge the already vast reach of constitutional prohibition beyond even the most extravagant modern interpretation of the Constitution"); Frederick Schaucr, Ashwander Revisited, 1995 SUP. CT. Rev. 71, 98 (maintaining that although the avoidance canon is widely viewed as a "vehicle of judicial restraint[,] ... [p]erhaps it is anything but," because its actual effect is to permit judges to "substitute their judgment for that of Congress" without assuming responsibility for rendering a constitutional holding).

98. See Fallon \& Meltzer, supra note 84, at 1800-01 (asserting that "there exists a substantial body of case law, rising almost to the level of a constitutional tradition, in which ... constitutional adjudication ... functions more as a vehicle for the pronouncement of norms than for the rcsolution of particular disputes," and linking this body of law to Marbury, in which, "[r]ather than observing the principle of strict necessity... the Court used William Marbury's case to resolve a number of important constitutional questions, but ultimately awarded no remedy"). 
court judgments furnishes one plain example. ${ }^{99}$ Since 1988, the Court's appellate jurisdiction has been almost entirely discretionary. ${ }^{100}$ By the time that thc Court considers a case, trial and typically appeal have already occurred; there is neither statutory nor constitutional necessity of further review. ${ }^{101}$ Rather, in choosing which cases to decide, the Court considers which issues most deserve its attention in light of the public interest in achieving clarity and uniformity in constitutional law. ${ }^{102}$ After granting review, the Court routinely issues broad pronouncements, not rulings narrowly tailored to the case before it. ${ }^{103}$ In order to achieve doctrinal clarification on multiple fronts, the Court occasionally renders alternative holdings. ${ }^{104}$ The Court has also emphasized its own special function in the constitutional regime by insisting that its views of what the Constitution requires, once pronounced, bind all branches of government in future cases, not merely the parties whose rights were adjudicated. ${ }^{105}$ Citing Marbury, the Court has thus held that Congress cannot expand the substantive reach of constitutional rights beyond previous judicial definitions, even when acting pursuant to Section 5 of the Fourteenth Amendment, which authorizes Congress to "enforce, by appropriate legislation, the provisions of this article." 106

A number of doctrines applied by lower courts similarly reflect Marbury's special-functions face by recognizing public interests-partly distinct from the personal rights of the parties - in the declaration and enforcement of constitutional norms. For example, in a variety of settings, a litigant may invoke "third-party standing" and seek judicial relief based not

99. See generally Edward A. Hartnett, Questioning Certiorari: Some Reflections Seventy-Five Years After the Judges' Bill, 100 CoLum. L. REv. 1643 (2000) (criticizing the certiorari jurisdiction and its impact on the Supreme Court's sense of its role in the constitutional scheme).

100. See Bennett Boskey \& Eugene Gressman, The Supreme Court Bids Farewell to Mandatory Appeals, in 109 S. Cr. 109 (1988).

101. See Hartnett, supra note 99, at 1714-15 (observing that the Court's certiorari practice "completcly undercuts" the rationale of Marbury's private-rights face that "judicial review is the byproduct of a court's obligation to decide a case"); Daniel J. Meltzer, The Judiciary's Bicentennial, 56 U. CHI. L. Rev. 423, 430 (1989).

102. See Sup. Cr. R. 10 (1999) (listing among the factors that the Court considers in determining whether to grant certiorari whether a state court or court of appeals has "decided an important federal qucstion in a way that conflicts with the decision" of another court and whether "a state court or a United States court of appeals has decided an important question of federal law that has not been, but should be, scttled by this Court"). According to Edward Hartnett, the Court's agenda-setting capacity far outruns the private rights rationale in Marbury that judicial review is merely an incident of the necessity to decide cases and instead endows the Court with a policy-making function. Hartnett, supra note 99 , at $1718-19$.

103. For a defense of Supreme Court practice in articulating clear rules to govern decisions by lower courts in future cases, see Antonin Scalia, The Rule of Law as a Law of Rules, $56 \mathrm{U}$. CHI. L. Rev. $1175,1178-79$ (1989).

104. See Fallon \& Meltzer, supra note 84, at 1801.

105. See Cooper v. Aaron, 358 U.S. 1, 18 (1958) (equating the Court's interpretation of the Constitution in a decided case with "the supreme law of the land").

106. City of Boerne v. Flores, 521 U.S. 507, 517 (1997). 
on her own constitutional rights, but on the rights of persons not before the court. ${ }^{107}$ The obvious aim is to protect public and third-party rights. The notion that the judiciary has a special function of broadly assuring adherence to constitutional norms also finds manifestation in First Amendment overbreadth doctrine, which permits courts to invalidate entire statutes at the behest of parties whose own conduct is not constitutionally protected to ensure that others are not "chilled" in the exercise of protected speech rights. ${ }^{108}$

Mootness doctrine contains additional reflections of Marbury's special-functions face. ${ }^{109}$ At its core, mootness doctrine embodies the premise of the private-rights model that courts will decide constitutional issues only as necessary to vindicate the personal rights of parties with concrete grievances. ${ }^{110}$ But the Court has introduced elements of flexibility to permit courts to fulfill their "special function" of declaring and broadly enforcing constitutional norms." ${ }^{111}$ A plain example resides in the traditional "exception" to mootness doctrine for cases "capable of repetition, yet evading review." 12 The unmistakable goal is to permit the courts to articulate and enforce constitutional norms that could not be vindicated effectively in private-rights disputes. ${ }^{113}$

107. See, e.g., Caplin \& Drysdale, Chartered v. United States, 491 U.S. 617, 623 n.3 (1989); Craig v. Boren, 429 U.S. 190, 192-96 (1976); NAACP v. Alabama, 357 U.S. 449, 459 (1958).

108. See Osborne v. Ohio, 495 U.S. 103, 116 n.12 (1990) ("In the First Amendment context, ...' [b]ecause of the sensitive nature of constitutionally protected expression, we have not required that those subject to overbroad regulations risk prosecution to test their rights. For free expression-of transcendent value to all society, and not merely to those exercising their rights-might be the loser."') (quoting Dombrowski v. Pfister, 380 U.S. 479, 486 (1965)); see generally Richard H. Fallon, Jr., Making Sense of Overbreadth, 100 YALE L.J. 853 (1991) (discussing the nature, scope, and rationale of overbreadth doctrine).

109. Mootness doctrine reflects the basic idea that " $[t]$ here is no case or controversy once the matter has been resolved." WRIGHT \& KANE, supra note 40, at 63 .

110. See id. at 61-62 (noting the general "case or controversy" limitation on judicial review and linking it to Marbury's argument that "a court has power to declare a statute unconstitutional only as a consequcnce of the power to decide a case properly before it").

111. See United States Parole Comm'n v. Geraghty, 445 U.S. 388, 400 (1980) (describing mootness as a "flexible" doctrine).

112. S. Pac. Terminal Co. v. 1CC, 219 U.S. 498, 515 (1911).

113. See Daniel J. Meltzer, Deterring Constitutional Violations by Law Enforcement Officials: Plaintiffs and Defendants as Private Attorneys General, 88 CoLum. L. Rev. 247, 301 \& n.309 (1988) (" [T] The origins of the doctrine betray concern about resolving issues that might otherwise evade review, in order to protect the rights of parties other than the litigant whose case is moot.").

Within the domain of mootncss doctrine, another example of the influence of Marbury's specialfunctions face comes from the Court's express abandonment, in Friends of the Earth, Inc. v. Laidlaw Envtl. Servs. (TOC), Inc., 528 U.S. 167, 190 (2000), of its characterization of mootness as the doctrine of "standing set in a time frame." See Arizonans for Official English v. Arizona, 520 U.S. 43, 68 n.22 (1997); Geraghty, 445 U.S. at 397 (1980). Expressly recognizing the public interest in achieving judicial resolution of issues, not just controversies, Friends of the Earth ruled that "there are circumstances in which the prospect that a defendant will engage in (or resume) harmful conduct may be too speculative to support standing, but not too speculative to overcome mootness." 528 U.S. at 190. 
The law of official immunity provides an especially vivid example of a doctrine reflecting a special-functions conception of the judicial role. In suits alleging constitutional violations, public officials ordinarily enjoy immunity from damages liability unless they violated "clearly established" rights. ${ }^{14}$ In implementing this immunity rule, the Supreme Court has stated that lower courts should decide first whether the right claimed by the plaintiff exists at all and only then determine whether it was clearly established at the time of the defendant's alleged conduct. ${ }^{115}$ If the Court wanted to avoid unnecessary resolution of constitutional issues, it would prescribe a different order of decision. It would direct the lower courts to begin by asking whether a claimed constitutional right, if it existed at all, was clearly established at the time of an alleged violation. If it is doubtful that a constitutional right existed at all, then the defendant could not have violated a "clearly established" right, and the damages claim could be dismissed on that basis. In cases of this kind, determination whether a constitutional right actually exists is not strictly necessary to decide the rights of the parties. Instead, the prescribed order of decision implicitly acknowledges the courts' special function of resolving uncertain constitutional issues for the benefit of the public. ${ }^{16}$

The special-functions face of Marbury may also be seen in various constitutional rights first recognized during the latter half of the twentieth century and in the conceptions of individual injury supporting standing to enforce those rights. ${ }^{117}$ To take just two examples, the injuries underlying

114. See Harlow v. Fitzgerald, 457 U.S. 800, 813-20 (1982).

115. See County of Sacramento v. Lewis, 523 U.S. 833, 842 n.5 (1998) (asserting that "the better approach is to determine the right before determining whether it was previously established with clarity").

116. See id. at 841 (reeognizing that to adhere to the avoidance canon would tend to leave citizens' rights and officials' duties "uncertain, to the detriment both of officials and individuals").

Further examples of doctrines under which the Court prescribes the determination of constitutional issues technically unnecessary to the decision of a particular case, presumably due to the public interest in having the issues resolved, can be found in a varicty of areas. In cases under the harmless-error doctrine, the Court has sometimes decided first whether constitutional error occurred, then either determined or remanded for a determination whether the error was harmless. See, e.g., Pope v. Illinois, 481 U.S. 497, 501-04 (1987). If an error is judged harmless, the ruling on the "merits" issue will turn out to be unnecessary to the ultimate decision to deny relief. Similar results can occur under United States v. Leon, 468 U.S. 897 (1984), which sometimes allows the introduction of evidence obtained through unconstitutional searches if an officer proeeeded in "good faith." The Court has indicated that courts may address the constitutional question before ruling on the good faith issue, see id. at 925-26, even though a ruling that a search violated the Constitution will be unnecessary to the ultimate disposition where "good faith" is found to exist. Once again, the justification for the order of decision must reside in a public interest in allowing the courts to specify the meaning of constitutional norms in order to guide official conduct in other cases.

117. See United States v. Richardson, 418 U.S. 166, 194-95 (1974) (Powell, J., concurring) (noting the occurrence of a "revolution in standing doctrine"); FALLON ET AL., supra note 5, at 136-37 (identifying a strain on standing doctrine resulting from "the increasing recognition of substantive constitutional rights" protecting interests besides property and traditional conceptions of individual liberty). 
suits to vindicate voting rights ${ }^{118}$ and rights under the Establishment Clause ${ }^{119}$ are typically "broadly shared" and "not associated with the kind of liberty or property interests protected by the common law." ${ }^{20}$ In finding such suits to be justiciable, the Supreme Court has never formally abandoned the requirement of concrete and particularized injury. Nonetheless, as Justice Powell once observed, some of its decisions have "threaten[ed]" to "transform [the concept of 'particularized injury'] beyond recognition." ${ }^{21}$ Commentators have linked the motivating concerns with a special-functions or "public rights" conception of the judicial role. ${ }^{122}$

\section{The Influence of the Political or Prudential Face}

Cases involving prudential decision making, and thus reflecting Marbury's prudential face, fall into two principal, partly overlapping categories.

First, in several areas the Supreme Court has appealed openly to prudential considerations in shaping doctrine and deciding cases. The doctrine of stare decisis presents a paradigm case. ${ }^{123}$ The Court has said expressly that when it "reexamines a prior holding, its judgment is customarily informed by a series of prudential and pragmatic considerations designed to test the consistency of overruling a prior decision with the ideal of the rule of law, and to gauge the respective costs of reaffirming and overruling a prior case." 124 In Planned Parenthood v. Casey, the Court notoriously cited its apparently prudential interest in maintaining the "perception" of its own legitimacy ${ }^{125}$ as a partial justification for its decision to reaffirm the

118. See FAllon ET AL., supra note 5, at 136, 181 (identifying voting-rights suits with a "public rights" or special-functions model and noting the conceptual difficulty in identifying the underlying injury in certain voting-rights cases).

119. See, e.g., Capitol Square Review \& Advisory Bd. v. Pinette, 515 U.S. 753 (1995) (entertaining an Establishment Clause challenge to a religious display on public property without adverting to the injury supporting standing); Allegheny County v. ACLU, 492 U.S. 573 (1989) (same).

120. FALLON ET AL., supra note 5, at 137.

121. Richardson, 418 U.S. at 194-95.

122. See, e.g., FALLON ET AL., supra note 5, at 136-37 (associating the recognition of standing to assert rights not linked to traditional liberty or property interests with a "public rights" or specialfunctions rather than a "private rights" model); Monaghan, supra note 44 , at $1380-83$ (describing the influence of the special-functions model on standing doctrine).

123. The doctrine of stare decisis reflects the authority of precedent, even when the precedent was initially mistaken. See, e.g., Richard H. Fallon, Jr., Stare Decisis and the Constitution: An Essay on Constitutional Methodology, 76 N.Y.U. L. REv. 570, 570 (2001); Michael Stokes Paulsen, Abrogating Stare Decisis by Statute: May Congress Remove the Precedential Effects of Roe and Casey?, 109 YALE L.J. 1535, $1538 \mathrm{n.8}(2000)$. The doctrine takes its name from the Latin maxim "stare decisis et non quieta movere - stand by the thing decided and do not disturb the calm." James C. Rehnquist, The Power that Shall be Vested in a Precedent: Stare Decisis, the Constitution, and the Supreme Court, 66 B.U. L. REv. 345, 347 (1986). Abundant authorities establish that "stare decisis is not an inexorable command"; it requires only that "a departure from precedent... be supported by some special justification." Dickerson v. United States, 530 U.S. 428, 443 (2000) (internal quotations omitted).

124. Planned Parenthood v. Casey, 505 U.S. 833, 854 (1992).

125. See id. at 865 . 
essential holding of Roe $v$. Wade. ${ }^{126}$ The Court reasoned that the public would cease to respect it as a principled decision maker if it appeared prone to overrule past, momentous decisions "under fire." ${ }^{27}$ It concluded on this basis that overruling would therefore require a "most compelling reason." 128

The Court has also acknowledged an expressly "prudential" element in standing doctrine. ${ }^{129}$ By the Court's own account, standing doctrine includes some requirements mandated by Article III, ${ }^{130}$ but also a series of judicially created prudential rules. ${ }^{131}$ Prominent among the prudential standing requirements is a rule that the courts will not hear "generalized grievances" shared by a large class of citizens. ${ }^{132}$ In justifying the denial of standing to plaintiffs who satisfy the Constitution's requirements, the Court has said that recognition of standing based on broadly shared injuries would be too likely to enmesh the judiciary in collisions with more democratically accountable institutions. ${ }^{133}$

A similar strand of prudentialism suffuses the "political question" doctrine, under which the Supreme Court deems "certain allegations of unconstitutional government conduct" to be "inappropriate for judicial review." 134 The political-question doctrine was directly prefigured in Marbury's assertion that "[q]uestions in their nature political, or which are,

126. 410 U.S. 113 (1973) (recognizing a constitutional right to abortion prior to the point of fetal viability).

127. Casey, 505 U.S. at 867.

128. Id.

129. See, e.g., Vallcy Forge Christian Coll. v. Ams. United for the Separation of Church \& State, 454 U.S. 464, 474 (1982); Warth v. Seldin, 422 U.S. 490, 499-502 (1975).

130. See, e.g., Valley Forge, 454 U.S. at 472 . The Court asserted that

at an irrcduciblc minimum, Art. III requires the party who invokes the court's authority to

"show that he personally has suffered some actual or threatened injury as a result of the putatively illegal conduct of the defendant," and that the injury "fairly can be traced to the challenged action" and "is likely to be redressed by a favorable deeision."

Id. (citations omitted).

131. Among the "judicially self-imposed limits" are "the general prohibition on a litigant's raising another person's legal rights, the rule barring adjudication of gencralized grievances more appropriately addressed in the representative branches, and the requirement that a plaintiff's complaint fall within the zone of interests protected by the law invoked." Allen v. Wright, 468 U.S. 737, 750-51 (1984).

132. See id.

133. See, e.g., Valley Forge, 454 U.S. at 474 (Powell, J., concurring). Justicc Powcll noted:

$[R]$ cpeated and cssentially head-on confrontations between the life-tenured branch and the representative branches of government will not, in the long run, be beneficial to cithcr. The public confidence essential to the former and the vitality crucial to the latter may well crode if we do not exercise self-restraint in the utilization of our power to negative the actions of the other branches.

Id. (quoting United States v. Richardson, 418 U.S. 166, 188 (1974)).

Whcre Congress expressly confers standing to sue based on widely shared but nonetheless constitutionally cognizable injuries, the merely "prudential" requiremcnts of standing doctrine give way, and the Court will uphold standing. See, e.g., Lujan v. Defenders of Wildlife, 504 U.S. 555, 578 (1992) (explaining Congress's power to "elevat[e] to the status of legally cognizable injuries concrete, de facto injuries that were prcviously inadequate in law" to confer standing).

134. Chemerinsky, supra note 35, at 143-44. 
by the constitution and laws, submitted to the executive, can never be made in this court." 135 Since Marbury, the political-question doctrine has not achieved much clarity of definition, ${ }^{136}$ but some judicial opinions and academic commentators openly recognize that prudential considerations influence the doctrine's application. ${ }^{137}$

The second category of prudential decision making, not entirely distinct from the first, encompasses cases in which the Supreme Court has shaped particular rulings (rather than entire doctrines) to avert public hostility but has not expressly acknowledged this motivation as a basis for decision. The absence of an express statement makes cases in this category difficult to identify with certainty. Marbury furnishes a case in point. Although most commentators have seen political motivations for the Court's decision, ${ }^{138}$ the opinion nowhere broaches this rationale, and it thus can be disputed that prudential considerations played any role. ${ }^{139}$ Nonetheless, critics have identified a number of decisions that were likely influenced by the Court's apprehension of adverse political consequences.

Naim v. Naim affords a notorious example. ${ }^{140}$ Naim, which came before the Court on appeal as of right, presented a challenge to the constitutionality of a Virginia statute forbidding interracial marriage. The case arose in the near aftermath of Brown v. Board of Education, which mandated an end to school segregation. ${ }^{141}$ In a memorandum read to his fellow

135. Marbury v. Madison, 5 U.S. (1 Cranch) 137, 170 (1803). Some commentators maintain that Marbury's definition of non-justiciable political questions was a narrow one. See, e.g., Chemerinsky, supra note 35, 145 (asserting that Marshall's definition in Marbury "[i]ncluded only ... matters where the President had unlimited discretion, and there was thus no allegation of a constitutional violation").

136. See, e.g., Martin Redish, Judicial Review and the "Political Question", 79 Nw. U. L. Rev. 1031,1031 (1985) (noting that commentators "have differed significantly about the doctrine's seope and rationale").

137. See, e.g., Nixon v. United States, 506 U.S. 224, 252 (1992) (Souter, J., concurring) (asserting that application of the political-question doctrine requires case-by-case attention to "prudential concerns"); B1CKEL, supra note 5, at 125-26 (asserting that the discretion exercised under the political question doctrine resists being characterized as "constitutional interpretation" and that "[t]here is ... something different about it, in kind not degree; something greatly more flexible, something of prudence, not construction and not principle").

Judge Posner has defended the Supreme Court's recent decision in Bush v. Gore, 531 U.S. 98 (2000), as supportable on prudential grounds under what he terms a "a reverse political questions doctrine." RICHARD Posner, Breaking the Deadlock: The 2000 Election, the Constitution, and the Courts 162 (2001). Posner argues that if Al Gore had prevailed in a Florida recount, Florida's legislature would have appointed an alternate slate of electors pledged to Bush, and that "there was a real and disturbing potential for disorder and temporary paralysis" due to a foreseeable division between the Republican-controlled House and the Democrat-controlled Senate. Id. at 143. Under these circumstances, Posner writes, "Political considerations in a broad, nonpartisan sense" made it important for the Court "to intervene." Id. at 162. But see Ward Farnsworth, "To Do a Great Right, Do a Little Wrong": A User's Guide to Judicial Lawlessness, 86 MinN. L. Rev. 227 (2001) (critiquing Posner's argument in light of the same kind of "pragmatic" considerations that Posner invokes in support).

138. See supra note 74 .

139. See supra note 74 (citing the view of Robert Clinton).

140. 350 U.S. 891 (1955).

141. 347 U.S. 483 (1954). 
Justices, Justice Frankfurter argued forcefully that the miscegenation issue aroused such deep emotions that a judicial pronouncement of invalidity would have the effect of "thwarting or seriously handicapping the enforcement of [our] decision in the segregation cases." ${ }^{\text {"142 }}$ Apparently persuaded, the Court remanded the case to the Virginia Supreme Court on the pretext that the record required clarification. ${ }^{143}$ On remand, the state court declared the record to be fully adequate and reinstated its former opinion. ${ }^{144}$ When the case returned to the Supreme Court, again on appeal as of right, the Court voted to deny review on the plainly disingenuous basis ${ }^{145}$ that the decision of the Virginia court in refusing to clarify thc record "leaves the case devoid of a properly presented fcderal question."146

Influential commentators have concluded that a series of nineteenthcentury cases revitalizing the doctrine of state sovereign immunity ${ }^{147}$ reflected plainly prudential considerations: The Justices feared that a judicial decision ordering the states of the former Confederacy to pay their debts would encounter defiance. ${ }^{148}$ it has also been suggested that reported threats by President Roosevelt to defy a contrary decision influenced the decision in Ex parte Quirin ${ }^{149}$ to uphold the trial of German saboteurs

142. The memorandum is quoted in Appendix D to Dennis J. Hutchinson, Unanimity and Desegregation: Decisionmaking in the Supreme Court. 1948-58, 68 GEo. L.J. 1, 95-96 (1979).

143. See Naim, 350 U.S. at 891.

144. See Michael Klarman, An Interpretive History of Modern Equal Protection, 90 MicH. L. Rev. 213, $243(1991)$.

145. See Herbert Wechsler, Toward Neutral Principles of Constitutional Law, in PRINCIPLE, Politics and Fundamental Law 47 (1961) (terming the result in Naim "wholly without basis in the law").

146. Naim, 350 U.S. at 985 .

147. At the historical core of the doctrine of sovereign immunity is the notion that the sovereign cannot be sued without its consent. See generally FALLON ET AL., supra note 5, at 1001-02 (discussing the foundations of sovereign immunity). Although it is much debated whether state sovereign immunity survived the ratification of the federal Constitution, the Supreme Court squarely held that it did not in Chisholm v. Georgia, 2 U.S. (2 Dall.) 419 (1793). Congrcss then responded by proposing the Eleventh Amendment, later ratified by the states, which provides that " $[t]$ he Judicial power of the United States shall not be eonstrued to extend to any suit in law or equity, commenced or prosecuted against one of the United States by Citizens of another State, or by Citizens or Subjects of any Foreign State." U.S. Const. amend. XI. Prior to the Civil War, thc Eleventh Amendment was narrowly construed. See, e.g., Cohens v. Virginia, 19 U.S. (6 Wheat.) 264, 293, 383 (1821) (construing the Eleventh Amendment as inapplicable to suits by citizens of the defendant state and to all cases, regardless of parties, "arising under the constitution or laws of the United States"). But the Court broke from its pattern of narrow construction in a series of late nineteenth-century cases culminating in Hans v. Louisiana, 134 U.S. 1 (I890) (holding that the Eleventh Amendment bars a federal suit against a state by a citizen of that state alleging a violation of the Constitution of the United States).

148. See, e.g., John J. Gibbons, The Eleventh Amendment and State Sovereign Immunity: A Reinterpretation, 83 CoLum. L. REv. 1889, 1983 (1983) (asserting that "unrelenting popular pressure ... actually dictatcd [the Court's] ultimate decision" in the culminating case of Hans $v$. Louisiana); David L. Shapiro, Wrong Turns: The Eleventh Amendment and the Pennhurst Case, 98 HaRV. L. Rev. 61, 70 (1984) (describing the Court's decision as motivated by "political exigencies" and a recognition that a judgment against the state would prove unenforceable).

149. 317 U.S. 1 (1942). 
apprehended in the United States during World War II by a military commission, not an Article III court. ${ }^{150}$

Even when prudential thinking is not self-conscious, Michael Klarman is surely right that the Justices' immersion in the prevailing sentiments of their times will often make anything other than a politically prudent decision "virtually unthinkable" despite otherwise formidable legal arguments supporting a claim of constitutional right. ${ }^{151}$ In illustration of his thesis, Klarman argues-without making claims about the Justices' actuaI thinking - that it would not have been "realistically possible" for the Court to have decided other than it did in the now vilified case of Plessy $v$. Ferguson, ${ }^{152}$ which held that a system of racially "separate but equal" railroad accommodations satisfied the Equal Protection Clause. ${ }^{153}$ Klarman makes similar arguments with respect to Korematsu v. United States, ${ }^{154}$ which upheld the forced relocation of persons of Japanese ancestry, American citizens not excepted, during World War II, and Dennis $v$. United States, ${ }^{155}$ decided during the height of the McCarthy era, which rejected the argument that prosecutions of Communists violated the First Amendment. ${ }^{156}$

The influence of Marbury's prudential face can also be seen, at least indirectly, in continuing judicial insistence that courts must balance considerations of private right against considerations of public interest in awarding equitable remedies. ${ }^{157}$ In the most famous invocation of this doctrine in modern times, the Supreme Court declined to order immediate enforcement of its landmark decision in Brown v. Board of Education. ${ }^{158}$ In the apparent hope of allowing public attitudes to accommodate themselves

150. See Bruce Ackerman, States of Emergency: Don't Panic, London Rev. of Books, Jan. 28, 2002, available at http://www.lrb.co.uk/v24/n03/acke01_html; see also William O. DOUglas, THE Court Years, 1939-1975, at 138-39 (1980) (reporting that "[t]he Attorney General, Francis Biddle, told the Court [in the Quirin case] that the claims of the saboteurs were so frivolous, the Army was going to go ahead and execute the men whatever the Court did"); Neal K. Katyal \& Laurence H. Tribe, Waging War, Deciding Guilt: Trying the Military Tribunals, 111 YaLE L.J. 1259, 1291 (2002) (asserting that "it also appears that some highly questionable ex parte arm-twisting by the executive may have spurred the Supreme Court's unanimous decision").

151. Michael J. Klarman, Rethinking the Civil Rights and Civil Liberties Revolutions, 82 VA. L. REv. 1, 26 (1996).

152. 163 U.S. 537 (1896).

153. Klarman, supra note 151 , at 26.

154. 323 U.S. 214 (1944).

155. 341 U.S. 494 (1954).

156. See Klarman, supra note 151, at 27-30.

157. See, e.g., Int'l Bhd. of Teamsters v. United States, 431 U.S. 324, 375 (1977) (insisting that "in formulating any equitable decree, a court must draw on the 'qualities of mercy and practicality [that] have made equity thc instrument for the nice adjustment and reconciliation between the public interest and private needs as well as between competing private claims'"); see generally Paul Gewirtz, Remedies and Resistance, 92 YALE L.J. 585, 598-608 (1983) (discussing interest balancing in the award of remedies for unlawful racial discrimination).

158. 347 U.S. 483 (1954). 
to the ruling, the Court said that it would suffice for desegregation to occur "with all deliberate speed." 159

In retrospect, many of the cases most easily characterized as involving covertly prudential decision making have been thought regrettable, even shameful. ${ }^{160}$ Especially for that reason, it is perhaps important to note that prudentially based adjudication in a narrow band of highly charged cases does not want for normative defenses. At least four such defenses merit brief mention.

First, there is a familiar consequentialist argument: Regrettably but justifiably, the Court must forego principled decision making in a few cases in order to preserve its capacity to function effectivcly in the much larger set of cases in which the public will tolerate, if not welcome, the Court's vindication of constitutional norms. ${ }^{161}$

Second, Alexander Bickel famously argued that a society generally eommitted to principle should not be denied arts of compromise, especially when the cost of adhering to principle would be inordinate. ${ }^{162}$ When an allthings-considered calculation favors expediency over rigidity, Bickel maintained that courts should employ devices that allow compromises to occur without affirming those compromises' constitutional validity. ${ }^{163}$

Third, I myself have argued that especially insofar as there is reasonable disagreement about what constitutional norms require, the Court should hesitate to impose its own morally laden judgments in the face of aroused popular sentiment to the contrary. ${ }^{164}$ Interests in the fair allocation of political power sometimes call for the Court to yield despite its own

159. Brown v. Bd. of Educ., 349 U.S. 294, 301 (1955) ("Brown IP"). For a discussion of the prudential foundations of the Court's decision in Brown $I /$, see RICHARD H. FAllon, JR., 1mplementing The Constitution 59-60 (2001). See generally Barry Friedman, When Rights Encounter Reality: Enforcing Federal Remedies, 65 S. CAL. L. Rev. 735 (1992) (arguing that judicial adjustment of rcmedies in light of majoritarian political opposition helps soften the countermajoritarian thrust of judicial review); Gewirtz, supra notc 157 (examining when and how courts should limit remedies in response to public opposition).

160. See, e.g., PERry, supra note 77, at 145 (tcrming Plessy "ridiculous and shameful"); Ronald Dworkin, Mr. Liberty, N.Y. REv. of Books, Aug. 11, 1994, at 17, 20 n.4 (labeling Dennis "shameful").

By contrast, some decisions that seem equally difficult to rationalize by reference to previous authorities seem to have won acccptance or even hesitant applause, perhaps because the right the Court declined to enforce has fallen into normative disfavor. As an example, Judge Posner cites Home Bldg. \& Loan Ass' $n$ v. Blaisdell, 290 U.S. 398 (1934), in which the Court upheld a Depression-era debtors' relief statute arguably in the teeth of the constitutional prohibition against state impairments of the "Obligations of Contracts," U.S. Const. art. 1, \$10, cl. 2. See Posner, supra note 137, at 173.

161. See, e.g., MCCloskey, supra note 19, at 228-31 (arguing that the Court must not jeopardize its capacity to function as an overall force for good by rendering politically unacceptable decisions on issues of central political concern).

162. BICKEL, supra note 5, at 64,68 .

163. Id. at 69-72. Bickel argues that the Court should use devices such as justiciability doctrines to avoid ruling on the constitutional merits and thereby escape the necessity to choose between "legitimating" a statute that is inconsistent with sound constitutional principles and precipitating a collision with ascendant political forces. Id. at 70-71.

164. FALLON, supra note 159, at 51-52. 
conscientious judgment that a claim of constitutional right should otherwise prevail. ${ }^{165}$

Fourth, Cass Sunstein has argued that courts should not insist on upholding novel claims of constitutional right when a "favorable" decision would predictably trigger a public backlash with adverse consequences for the rights-holders. ${ }^{166}$ In illustration of this position, Sunstein argues that a contemporary court should not recognize a constitutional right to gay marriage, even if the court believed that such a right ought to exist as a matter of constitutional principle:

If the [Court] accepted the view that all states must authorize samesex marriages in 2001 , or even 2003 , we might well expect a constitutional crisis, a weakening of the legitimacy of the Court, an intensifying of hatred of homosexuals, a constitutional amendment overturning the Court's decision, and much more. Any court should hesitate in the face of such prospects. ${ }^{167}$

\section{III}

\section{Conflicts Among the Faces}

Although Marbury's three faces all have enduring resonance in contemporary legal doctrine and in widely shared understandings of the judicial function, it scarcely needs demonstration that those faces, and the strands of doctrine and thought that they support, exist in tension with one another.

To begin with, Marbury's private-rights face conflicts overtly with both the special-functions and prudential theories of the judicial role. ${ }^{168}$ According to the private-rights model, courts are justified in pronouncing on constitutional issues only insofar as they must do so to resolve concrete disputes. As discussed above, numerous doctrines rest on this foundation. ${ }^{169}$ For example, standing rules require concrete adversity between the parties, and the avoidance canon calls for courts to decide constitutional issues only as a last resort. Obviously, however, these limitations on the judicial role are in tension with Marbury's special-functions face, which postulates the general, systemic importance of judicial resolution of

165. In offering this argument, I have distinguished between defensible decisions not to recognize a right for the first time and decisions, which 1 believe indefensible, to refuse to enforce wellestablished rights due to fear of adverse reaction. See id. at 53-55.

166. Cass Sunstein, One Case at a Time: Judicial Minimalism on the Supreme Court $161-62$ (1999).

167. Id.

168. See Wechsler, supra note 82, at 1006 ("Federal courts, including the Supreme Court, do not pass on constitutional questions because there is a spccial function vested in them to enforce the Constitution or police the other agencies of government," but because "they must decide a litigated issue that is otherwisc within their jurisdiction and in doing so must give effect to the supreme law of the land").

169. See supra text accompanying notes $98-102$. 
constitutional issues and welcomes judicial decision making that is not strictly necessary to resolve concrete disputes between particular individuals. Again at the risk of laboring the obvious, all of the doctrines that I cited above to illustrate the continuing influence of the special-functions face demonstrate this incompatibility. When the Supreme Court exercises its certiorari jurisdiction, its resolution of constitutional issues is not "necessary" in a strict sense; the case has already been decided by a lower court, whose judgment the Court need not review. ${ }^{170}$ Instead, the Court accepts jurisdiction based on its assessment of the public interest in having a particular issue decided at the highest level. The Supreme Court sometimes decides cases on broad bases, which are not required to resolve the particular dispute before it, to give guidance to other courts in other cases. ${ }^{171}$ Indeed, some doctrines require lower courts to decide issues not strictly necessary to determine the rights of the parties before them. For example, in qualified immunity cases, the district courts first pronounce on whether the plaintiff has asserted a cognizable constitutional right at all, and only then ask whether that right was sufficiently "clearly established" to support a damages recovery. ${ }^{172}$ As I also pointed out above, courts could sometimes avoid pronouncing on whether a disputed right exists if they were permitted to rule that, even if an asserted right did exist, it was not clearly established at the time of the alleged violation. ${ }^{173}$

By no means do these tensions arise solely from recent doctrinal innovations. As I have noted already, the tension between Marbury's privaterights and special-functions faces emerges from even a cursory reflection on Marbury itself. In one part of the opinion, Chief Justice Marshall suggested that the Court's authority to resolve constitutional issues derived solely from the necessity of adjudicating claims of individual rights. ${ }^{174} \mathrm{In}$ other parts of the opinion, however, Marshall uttered a number of constitutional conclusions, such as the amenability of the secretary of state to judicial process ${ }^{175}$ and the necessity of a remedy for every legal right, ${ }^{176}$ that were in no way necessary to the ultimate holding that the Court lacked jurisdiction to decide the case.

It is equally plain that Marbury's private-rights face, which suggests that it would be "treason to the constitution"

170. See supra text accompanying notes 100-03.

171. See supra text accompanying notes 103-04.

172. See County of Sacramento v. Lewis, 523 U.S. 833, 841 n.5 (1998) (asserting that "the better approach is to determine the right before determining whether it was previously established with clarity").

173. See supra text accompanying notes 114-16.

174. Marbury v. Madison, 5 U.S. (1 Cranch) 137, 170 (1803) ("The province of the court is, solely, to decide on the rights of individuals ....").

175. See id. at 169-73.

176. Id. at 163 .

177. Cohens v. Virginia, 19 U.S. (6 Wheat.) 264,404 (1821) (Marshall, C.J.). 
vindicate a valid claim of constitutional right in a case properly before it, ${ }^{178}$ contradicts its political or prudential face, which counsels avoidance of rulings that would provoke threatening confrontations with the political branches. Constitutional thought and doctrine reflect this conflict. Showing the influence of the private-rights face, various doctrines acknowledge a judicial obligation to resolve all properly presented issues necessary to the decision of justiciable cases. ${ }^{179}$ Similarly, the notion that courts must vindicate rights even, and perhaps especially, in the face of majoritarian pressures is widely celebrated. ${ }^{180}$ Yet the Supreme Court points explicitly to prudence as a justification for judicial doctrines denying standing in cases in which the Constitution would allow standing. ${ }^{181}$ Moreover, despite a general judicial reluctance to rest decisions openly on political or prudential considerations, commentators have plausibly identified a number of Supreme Court decisions that are difficult to explain except in prudential terms. ${ }^{182}$ There is also evidence tending to support claims that courts, at least occasionally, manipulate doctrine in order to achieve affirmative results that they believe prudent or desirable. ${ }^{183}$ This practice plainly contradicts the mandate of the private-rights face, which holds that "[t]he province of the court is, solely, to decide on the rights of individuals ...." ."184

Just as Marbury's private-rights face wars with its special-functions and prudential faces, the special-functions and prudential faces are often at odds with each other. According to the special-functions model, it is the constitutional mission and obligation of the judicial branch to declare

178. See supra text accompanying notes $47-48$.

179. See supra text accompanying notes $84-88$.

180. The most famous reference point for this view is United States v. Carolene Prods. Co., 304 U.S. 144, 153 n.4 (1938) (observing that courts may need to be especially searching in their review of legislation reflecting "prejudice against discrete and insular minorities... which tends seriously to curtail the operation of those political processes ordinarily to bc relicd upon to protect minoritics). See also Chambers v. Florida, 309 U.S. 227, 241 (1940) (asserting that courts act "as havens of refuge for those who might otherwise suffer because they are helpless, weak, outnumbered, or because they are nonconforming victims of prejudice and public excitement"); Klarman, supra note 151, at 1 (noting that "[i]t is common wisdom that a fundamental purpose of judicial review is to protcct minority rights from majoritarian overreaching").

181. See supra text accompanying notes 129-133.

182. See supra text aceompanying notes $138-156$.

183. For example, Duke Power Co. v. Carolina Envtl. Study Group, Inc., 438 U.S. 59 (1978), in which the Court overcame a variety of justiciability obstacles on the way to upholding the constitutionality of a federal statute crucial to the development of nuclear power, is often cited as a case in which the Court cngaged in doctrinal manipulation in order to achieve a substantive result that it believed prudent. See, e.g., FALLON ET AL., supra note 5, at 150 (terming Duke Power "virtually impossible to reconcile with prior authority" and characterizing it as "most plausibly explained as responsive to ad hoc considerations-especially the desire to reverse on the merits the district court's ruling that an important federal statute was unconstitutional"); Jonathan D. Varat, Variable Justiciability and the Duke Power Case, 58 TEx. L. Rev. 273 (1980) (citing Duke Power as an instance of "variable justiciability").

184. Marbury v. Madison, 5 U.S. (1 Cranch) 137, 170 (1803). 
constitutional norms and enforce them against the political branches. ${ }^{185}$ This injunction is difficult, if not impossible, to square with the prudential counsel that courts should sometimes avoid the articulation of constitutional norms in order to avoid collisions with majority sentiments. The tension becomes more acute in light of the justification for the specialfunctions model: Courts are the governmental institution best designed to grasp and articulate the true, sometimes exacting, import of constitutional norms. Once again, Marbury itself illustrates the conflict. Whcreas Marbury's special-functions face assumes that the judiciary must decide constitutional issues to ensure that constitutional decisions are untainted by politics, the surrounding facts-which give the case its prudential facesuggest that the Court itself functioned as a prudent political actor. ${ }^{186}$

\section{IV}

\section{Strategies for Making Sense of Dissonance}

As I explained in the Introduction, for those with an internal perspective on constitutional practice, awareness of the conflict generated by Marbury's three faces tends to produce cognitive dissonance. ${ }^{187}$ Most proponents of conventional constitutional arguments, which purport to derive conclusions from doctrinal premises, are likely to presuppose the mutual consistency of constitutional rules, doctrines, and precedents, at least much of the time. ${ }^{188}$ When that presupposition is directly challenged, the theory of cognitive dissonance predicts that insiders to constitutional practice will pursue a strategy for restoring harmony among their beliefs about constitutional law or for explaining coherently how to carry on with constitutional argument despite revealed tensions among foundational premises. ${ }^{189}$ There are undoubtedly myriad ways of coming to terms with tensions or contradictions in constitutional doctrine. Here I shall sketch only a handful of strategies, perhaps idiosyncratically denominated as interpretivism, reformism, historicism, realism, and postmodernism. As embodied in my somewhat stylized models or ideal types, all of these strategies at least loosely reflect prominent strands in the literature on constitutional law and theory, even if my accounts do not precisely describe the views of particular

185. See supra text accompanying notes $52-57$.

186. See supra text accompanying notes $74-75$

187. See supra text accompanying notes 7-11.

188. See, e.g., KenNeDY, supra note 13, at 180 (asserting that judges, "and their informed audience, 'deny,' in the psychological sense of the word, the influence of ideology" on adjudication and that they do so in order to avoid needing to confront contractions in "the role constraints under which judges operate"); Scordato, supra note 9, at 389 ("[L]aw students frequently carry with them into class powcrful assumptions about the coherence, rationality, and substantiveness of lcgal rules and lcgal doctrine.").

189. See generally Balkin, supra note 6, at 146 (describing how people apply "various strategies of cognitive dissonance reduction" in dealing with beliefs or suggestions that legal norms are incoherent or unfair). 
thinkers. ${ }^{190}$ In addition, each of the five strategies represents a plausible response to the specific doctrinal tensions traceable to Marbury, even though not all have been specifically applied to Marbury and its three faces in the extant literature. ${ }^{191}$

The fundamental goal of each strategy is to reconcile or explain doctrinal tensions in a way that enables participants in constitutional practice to sustain a coherent, facilitative understanding of what they and others do in offering constitutional arguments. The standards for assessing these strategies include requirements of intellectual rigor, but they are also partly psychological and thus variable from person to person: Approaches that produce a sense of understanding and empowerment in some people may fail to do so in others. Although the range of possible strategies is vast if not limitless, it is not surprising that a handful should predominate at any particular time. The most prominent strategies are exhibited in law school teaching and surrounding literatures, and adherents provide mutual encouragement and support. ${ }^{192}$

\section{A. The Nature of the Challenge}

In attempting to fathom the challenge that doctrinal tension poses, it may help to press harder on a notion to which I have appealed already, that

190. As introduced by Max Weber, ideal types are intellectual constructs developed through a synthesis of familiar positions. See MAX WEBER, ECONOMy AND Society: AN Outline of INTERPRETIVE SOCIOLOGY 19-22 (Guenther Roth \& Claus Wittich eds., 1978). Although based on real phenomena, ideal types exhibit a possibly oversimplified "conceptual purity" that "cannot be found in reality." Carl G. Hempel, Aspects of Scientific Explanation 156 (1965). Ideal types can be approached or approximated, however, and "concrete phenomcna can . . . bc compared for the purpose of explicating some of their significant components." Id.

191. There is admittedly no magic in the number five. My selections reflect an impressionistic sense that the five identified strategies are the ones most commonly deployed by commentators, lawyers, and law students to meet the intellectual and psychological challenges that doctrinal tensions or contradictions create for "insiders" to constitutional discourse. But I could also have discussed "pragmatism" or "neopragmatism" of the kind recently championed by Judge Posner. See infra note 267 (distinguishing Posner's pragmatism from postmodernism). Critical race theory would be another candidate for discussion. See, e.g., Critical Race Theory: Key Writings That Formed the Movement (Kimberlc W. Crenshaw et al. eds., 1996); Critical Race Theory: The Cutting Edge (Richard Delgado \& Jean Stefancic eds., 2d ed. 1999). The problem is that there is no obvious stopping point; any distinctive approach to legal analysis would be a plausible candidate for discussion. Rather than attempting to compile the most exhaustive possible catalogue, 1 have identified the five strategies that seem to me to be the most prominent and drawn a line on grounds that 1 acknowledge to be largely impressionistic.

192. Those who predominantly follow a particular strategy are thus analogous to what Stanley Fish calls "interpretive communities," defined by characteristic assumptions, values, and outlooks that determine their reading of both literary and legal tests. See STANLEy Fish, Is There a TEXT IN THIS CLASS? 13-14 (I980); Stanley Fish, Working on the Chain Gang: Interpretation in Law and Literature, 60 TEx. L. REv. 551, 552 (1982). For purposes of constitutional law, Fish writes, the different interpretive communities are defined by their inclinations "to ask different questions, to consider different bodies of information as sources of evidence, to regard different lines of inquiry as relevant or irrelevant, and, finally, to reach different determinations of what the Constitution 'plainly' means." Stanley Fish, Fish v. Fiss, 36 Stan. L. REv. 1325, 1336 (1984). 
of an "internal point of view" on constitutional argument. ${ }^{193}$ It is possible to distinguish stronger and weaker interpretations of what it means to hold an internal point of view. In a strong version, an internal point of view presupposes the capacity of constitutional doctrines to function as both evaluative and prescriptive norms. ${ }^{194}$ Adherence to this position is sociologically and psychologically familiar. Some people believe that constitutional law would be a fraud, and participation in constitutional argument personally dishonest, if such argument pervasively reflected opportunistically selected premises and embodied demonstrable fallacies ${ }^{195}$ - as would be the case if legal doctrine abounded in contradictions from which nothing could be validly proven. For someone with this sense of the coherence neeessary to support an internal point of view, a strategy for dealing with doctrinal tension or apparent contradiction could succeed only by discovering or creating an actual harmony within existing constitutional law.

In a weaker interpretation, however, the internal point of view is simply that of a participant in constitutional argument, as distinguished from that of an outside observer. ${ }^{196}$ After perhaps being initially startled by apparent contradictions in constitutional doctrine, some people may realize, whether consciously or subconsciously, that the acknowledgment of doctrinal contradiction fits relatively comfortably into their overall scheme of beliefs. As I noted above, a belief that the law is tension-ridden or contradictory may cohere with and tend to support a settled political view that the law is unfair. ${ }^{197}$ Similarly, those who regard life as generally rife with contradiction and irony may easily assimilate the view that the law, too, abundantly displays these features. People with attitudes such as these are less likely to feel a personal stake in the overall eoherence of constitutional

193. See supra note 6 and accompanying text.

194. This version is suggested, but not entailed, by the initial formulation of the "internal aspect" of legal rules offered in HART, supra note 6, at 56. Hart asserts that the "internal aspect" necessary for rules to exist within a community or practice

is that there should be a critical reflective attitude to certain patterns of behavior as a common standard, and that this should display itself in criticism (including self-criticism), demands for conformity, and in acknowledgments that such criticism and demands are justified, all of which find their characteristic cxpression in the normative terminology of "ought", "must", ld. and "should", "right" and "wrong".

195. See generally KENNEDY, supra note 13, at 192-212 (describing "denial" as a characteristic psychological response of judges who apprehend that their role requires thcm to make political choices of a kind that thcir role also appears to forbid them to make).

196. Cf. Balkin, supra note 6 , at 128 (noting that "thcre can bc more than one intcrnal perspectivc" reflecting the diverse purposes of diffcrent people in seeking to understand how legal rules function as "norms for conduct").

197. See supra text accompanying note 15 . 
norms than are those with stronger predispositions to regard legal norms as both action-guiding and morally justified. ${ }^{198}$

For such skeptical or critical participants in constitutional practice, there is less psychological imperative to discover or establish doctrinal coherence than to understand to what extent constitutional practice is or is not conflict-ridden, manipulative, and so forth. If constitutional doctrine and argument do not determine conclusions in the way that they seemingly purport to do, perhaps the appropriate emphasis is on the "seemingly." On this view, the advocate of a constitutional argument is no more morally committed to believing its truth than stage actors are committed to believing their lines. ${ }^{199}$

In presenting a series of strategies for dealing with perceived tensions at the foundations of constitutional law, I mean to offer at least partially sympathetic portraits. Each of the strategies described below has forceful, intellectually sophisticated proponents. None lacks allure. Yet each of the strategies is only that; there are no guarantees of success. Furthermore, none of the strategies for dealing with tensions in constitutional thought and doctrine is capable of generating a constitutional theory that satisfies all of the criteria that every participant in constitutional argument might reasonably uphold.

The reason that each strategy falls short of universal acceptance follows from the nature of the diverse yet overlapping challenges to which the apprehension of doctrinal tension gives rise. Some of the challenges are cognitive: We aspire to understand the meaning of legal doctrines partly in order to understand how they should be applied correctly; ${ }^{200}$ giving up too soon on the search for coherence is to abandon the aspiration to doctrinal mastery. We also aspire to understand constitutional practice in terms that can be reconciled with the teachings of the humanities and soeial sciences.

Other challenges are less cognitive and more pressingly practical or instrumental. These arise from felt needs for guidance about how to go on successfully in constitutional practice, in one or another of the ways in which success might be measured. Partly overlapping the practical challenges are moral ones. As I have noted already, some would regard it as dishonest and hypocritical to engage in a conflict-ridden constitutional practice that is incapable of supporting valid arguments. ${ }^{201}$ In the view of

198. Cf. Balkin, supra note 6, at 146, 152 (noting that some people's sense of self-identity is implicated in their understandings of the legal system and that they thus have an "ontological stake" in its coherence).

199. Cf. ARThur ISAK Applbaum, Ethics fOR AdVersaries 104-09 (1999) (examining the question of whether lawyers are "liars" and, more generally, when role-based efforts to deceive should be deemed morally acceptable).

200. See Balkin, supra note 6, at 151 ("When we attempt to understand legal norms so that we can apply them to specific situations, we must begin with the presumption that they make sense--that they represent an intelligible and defensible scheme of regulation.").

201. See supra text accompanying note 195. 
others, however, to achieve and articulate too sympathetic an understanding of legal doctrine, in which seeming contradictions are explained away and immanent harmony revealed, would be to implicate oneself in discreditable apologetics. ${ }^{202}$

Besides being diverse, these challenges are refracted through the complex and varied psychologies of individual human beings. Each of us approaches constitutional practice with a different set of attitudes and beliefs with which our understanding of constitutional doctrine must be reconciled. ${ }^{203}$ In addition, different people have different reasonable demands and purposes ${ }^{204}$ and they assign different priorities even to shared purposes. Under these circumstances, a theory or perspective that satisfies the most urgent intellectual, practical, and psychological needs of some will predictably fail to answer the most pressing demands of others.

\section{B. The Strategies Explained}

\section{Interpretivism}

Among the deepest assumptions of traditional legal analysis is that the law, no matter how jumbled or contradictory it may appear on the surface, in fact reflects immanent, logically consistent principles of justice. ${ }^{205}$ This assumption receives its most profound defense in the jurisprudential writings of Ronald Dworkin, ${ }^{206}$ from whom I derive the term "interpretivism." 207 But the label "doctrinalism" might as easily apply, for the assumption of immanent order also marks what Richard Posner terms "doctrinal" scholarship. ${ }^{208}$ Doctrinalists, as he defines them, try to identify

202. Cf. Balkin, supra note 6 , at 164 (describing the pressures that can lead to the moral "cooptation" of law students who "turn all [their] efforts to the task of understanding the law and to forging an agreement between [their] own views and those" immanent in the body of law that they are striving to understand).

203. Id. at 146 (applying the theory of cognitive dissonance to conclude that "[p]eople will have a need to alter their beliefs about the legal system... only if their beliefs about the coherence or incoherence of legal norms produce a significant conflict with their other commitments ...").

204. See id. at 128-29. Balkin asserts:

Consider five different purposes for understanding the law. First, we may wish merely to make sense of the law as a coherent scheme of regulation in order to learn it or apply it. Second, we may want to predict what other legal actors will do. Third, we may wish to describe the law in order to persuade others to interpret the law in our favor. Fourth, we may offer a critical portrait of the existing law in the hope of persuading others to change the law. Fifth, we may wish to understand law in terms of its practical effects rather than in terms of the content of its doctrines.

Id.

205. See id. at $154-56$ (explaining how the understanding and application of legal doctrine requires "rational reconstruction").

206. See, e.g., Dworkin, supra note 6; Ronald Dworkin, Taking Rights Seriously (1977).

207. Dworkin characterizes law as an "interpretive concept," Dworkin, supra note 6, at 87 , and argues that lawyers must develop "interpretive" theories both of legal practice as a whole and of particular bodies of doctrine. See id. at 87-94.

208. See Richard A. Posner, Overcoming Law 83-84 (1995). Posner asserts: 
"patterns in the cases or, failing that, to impose" patterns of their own. ${ }^{209}$ Likewise, lawyers' briefs and judicial opinions characteristically purport to identify an underlying coherence among legal rules, principles, and policies, revealing the single, legally correct answer to even the most contested questions. $^{210}$

The assumption that an immanent order lies beneath the surface tensions of legal doctrine is, of course, only an assumption. No hidden god of law guarantees that coherence will obtain; ${ }^{211}$ seekers of legal truth cannot expect simply to find an intelligible order in the way that an archaeologist might find a lost artifact. Rather, the student, scholar, judge, or lawyer must use imagination and sometimes moral judgment to develop the "best" understanding of relevant legal materials. ${ }^{212}$ Normally, the best understanding will be one that explains how statements that appear contradictory on their faces can be reconciled as presenting the different rules appropriately applicable to different kinds of cases. ${ }^{213}$

Confronted with the dissonance generated by Marbury, an interpretivist would begin with the working assumption that the case's three faces do not contradict one another, but rather reflect principles that have different weights or apply to different types of cases. For example, an interpretivist might start with the private-rights face and the proposition that courts have to vindieate individual rights in cases properly before them. In order to be reconciled with Marbury's prudential face, the duty to vindicate private rights would need to be cast as a principle, not an inviolable rule. ${ }^{214}$ To mark the boundary indicating when that principle properly yields to

The traditional law professor is above all a student of legal doctrine. What he does, mainly, in a legal system such as that of the Unitcd States which is orientcd toward case law is to read judicial opinions and try to find the pattcrn in the cases or, failing that, to impose one of his own. Doctrinalists are law's Talmudists. They proceed from the wclter of particular cases. The theory that guides their inquiry is muted, tacit, traditional. When they make arguments for reform they make them from within the tradition, using fragments of ethical or policy analysis found in the cases.

Id.

209. Id. at 83 .

210. See Smith, supra note 13 , at 1042 (noting that lawyers characterize the law as yielding "univoeal conclusions").

211. Cf. Pierre Schlag, Law as the Continuation of God by Other Means, 85 CaLIF. L. Rev. 427 (1997) (arguing that arguments purporting to cstablish legal objectivity and determinism resemble attempted fallacious proofs of the existence of God).

212. See DwOrKIN, supra note 6, at 256-57 (asscrting that a judge "must choose betwcen eligible interpretations by asking which shows the community's structure of institutions and decisions-its public standards as a whole-in a better light from the standpoint of political morality" and must depict the public "political record [as] the best it can be overall"); Richard H. Fallon, Jr., A Constructivist Coherence Theory of Constitutional Interpretation, 100 HaRv. L. Rev. 1189, 1231-37 (1987) (defending a similar approach).

213. See Balkin, supra note 6 , at 154-56 (describing the process of "rational reconstruction" of legal doctrine).

214. Cf. Fallon \& Meltzer, supra note 84, at 1787-91 (casting Marbury's apparent promise of a remedy for every legal right as a "principle," not a "command," that can sometimes yield to the competing policies reflected in doctrines of sovereign and official immunity). 
prudentialism, an interpretivist would attend to the case law, seeking an account that would fit it tolerably well. ${ }^{215}$ But moral judgment could be required too. For example, an interpretivist might, but need not, prefer an explanation that limited prudentialism to exceptional cases-for instance, those in which a judicial effort to enforce private rights would trigger a backlash, not merely against the courts, but against the very persons and interests that the courts would otherwise be obliged to protect. ${ }^{216}$

If Marbury's private-rights and prudential faces could be reconciled, an interpretivist would also attempt to specify when the courts properly perform special functions beyond the vindication of traditional private rights. For example, a theorist might identify a defensible judicial tendency to adopt a special-functions approach when, but only when, the most affected parties would be unable to assert their own rights, ${ }^{217}$ or the integrity of the political or judicial process would otherwise be at risk, ${ }^{218}$ or other criteria are satisfied.

Having thus illustrated how an interpretivist might attempt to deal with Marbury's three faces, I emphasize that I do not mean to endorse the sketchy account that I just offered. I have intended only to model a possible, familiar, indeed traditional legal response to dissonance in constitutional doctrine. Neither, however, should I distance myself too much. Most of my own work reflects an interpretivist perspective, ${ }^{219}$ partly because I find it temperamentally congenial and partly, especially in my teaching, because it reflects the form of arguments made in briefs and other submissions to courts. Within the prevailing norms of legal practice, an effective argument to a court must purport to demonstrate that the law, correctly understood, yields a preferred result.

Although my own affinity for interpretivism is strong, and although it models the characteristic approach of most doctrinal analysts and of many more philosophical commentators, ${ }^{220}$ experience makes plain that an

215. See Dworkin, supra note 6 , at 255 (discussing the requirement that a good legal theory must fit the extant materials at least tolerably well).

216. See SunSTEIN, supra note 166, at 161-62 (arguing that courts should not declare and enforce rights under such circumstances).

217. The Supreme Court has often cited this as a eonsideration in upholding third-party standing. See, e.g., Griswold v. Connecticut, 381 U.S. 479, 481 (1965) (allowing a doctor to assert the rights of married couples to utilize contraceptives because "the rights of husband and wife, pressed here, are likely to be diluted or adversely affected unless those rights are considered in a suit involving those who have this kind of confidential relation to them"); NAACP v. Alabama, 357 U.S. 449, 459 (1958) (permitting an assertion of third-party rights "where constitutional rights of persons who are not immediately before the Court could not be effectively vindicated except through an appropriate representative before thc Court").

218. See, e.g., Powers v. Ohio, 499 U.S. 400 (1991) (upholding standing of a criminal defendant to assert that the prosecution had used peremptory challenges to exclude jurors of a race other than his own, even though the right being asserted was that of prospective jurors).

219. See, e.g., Fallon, supra note 212, at 1231-37 (defending a similar approach).

220. See supra text aecompanying notes 205-10. 
interpretivist perspective will not satisfy everyone. People who believe the prevailing regime to be substantially unjust often regard the interpretivist strategy as a form of apologetics that would put them at risk of moral "co-optation." 221 Because interpretivism demands a sympathetic reconstruction of existing doctrine ${ }^{222}$ or an effort to portray it in the best moral light ${ }^{223}$ it may have the insidious effect of muting criticism. For those with strongly critical attitudes toward the prevailing constitutional order, the interpretivist perspective may thus appear uncongenial, if not psychologically impossible. ${ }^{224}$

Some also believe that interpretivist approaches tend to yield misleadingly idealized accounts of constitutional adjudication as a search for principled coherence among legal authorities. ${ }^{225}$ For them, interpretivist accounts are difficult to reconcile with beliefs, which they believe to be founded in human psychology and supported by the teachings of political science, ${ }^{226}$ that judges tend to decide cases based more on their personal values than on legal doctrine. ${ }^{227}$ However this criticism is judged, it is surely true that interpretivist theories are not designed to yield rigorous, testable predictions of judicial behavior. ${ }^{228}$ For anyone whose principal

221. See Balkin, supra note 6, at 160-61 (asserting that the quest for interpretive understanding "entails a quest for agreement with what we interpret" and "may result ... in our co-optation"); see also Roberto Mangabeira, The Critical Legal Studies Movement 119 (1986) (deriding an approach to legal analysis that "restate[s] power and preconception as right").

222. See Balkin, supra note 6, at 154-56.

223. Dworkin, supra note 6, at 256-57.

224. See Balkin, supra note 6 , at 146 ("[1]f an individual has an ontological stake in believing in the fundamental incoherence (or the fundamental injustice) of the legal and political system, she will tend to find unresolved moral conflicts and contradictions in various parts of the law because belief in their coherence might conflict with her precommitments.").

225. See, e.g., Michael Wells, Rhetoric and Reality in the Law of Federal Courts: Professor Fallon's Faulty Premise, 6 Const. Comment. 367, 376-77 \& n.20 (1989) (expressing doubt that judges are "deeply committed to principles of structure and judicial role" and opining that "raw ideology" exerts a greater influence).

226. Some political scientists believe that the Supreme Court pervasively pursues a policy agenda. See, e.g., Jefrrey A. Segal \& Harold J. Spaeth, The Supreme Court and the attitudinal. MoDEL 17, 62-73 (1993) (developing a testable "attitudinal model" according to whieh judges and Justices decide cases based solely on their ideological values and criticizing nontestable, nonpredictive approaches); Lee Epstein et al., The Supreme Court as a Strategie National Policymaker, 50 EMORY L.J. 583, 592-95 (2001) (hypothesizing that the Justices are "single-minded seekers of legal policy" but that they will temper their decisions, for strategic reasons, to "avoid reaching decisions considerably outside the range acceptable to the legislature and the president"). Most legal scholars reject this position, see, e.g., Stephen M. Griffin, American Constitutionalism: From Theory to Politics 138 (1996), as do many political scientists, see Keith Whittington, Taking what They Give Us: Explaining the Supreme Court's Federalism Offensive, 51 DukE L.J. 477, 485 (2001) (describing views of a "new institutionalist" school).

227. See, e.g., Michael Wells, Naked Politics, Federal Courts Law, and the Canon of Acceptable Arguments, 47 EMORY L.J. 89, $110-24$ (1998) (arguing that "naked politics is ubiquitous" in the shaping of federal courts' doctrine).

228. See Richard H. Fallon, Jr., Comparing Federal Courts "Paradigms", 12 Const. Comment. 3,12 (1995) (noting that the aim of certain types of legal scholarship is "not to predict outcomes, but to suggest, invoke, and elucidate some of the norms that help to constitute legal argument"). 
interest lies in predicting how judges will decide cases, especially in tension-ridden doctrinal areas; the interpretivist perspective will therefore seem inadequate.

\section{Reformism}

Like interpretivism, reformism aspires to establish the kind of doctrinal harmony necessary to support a strong version of the internal point of view, under which doctrinal norms are action-guiding and furnish valid premises for constitutional arguments. Whereas interpretivism seeks to rationalize the overwhelming preponderance of existing constitutional doctrine, reformism, which is a close cousin, acknowledges tension and contradiction that cannot be resolved by mere interpretation. Instead, reformism proposes to eliminate current tensions by retaining those doctrinal strands that reflect what the would-be reformer regards as the law's most normatively attractive values and by purging others.

An example of reformism comes from Owen Fiss's article, The Forms of Justice, which offers a sustained defense of adjudication pursuant to Marbury's special-functions face. ${ }^{229}$ "[T]he function of the judge," Fiss writes, "is not to resolve disputes, but to give the proper meaning to our public values. ${ }^{, 230}$ In asserting that various justiciability and equitable doctrines should be organized around this premise, Fiss does not deny the existence of competing doctrinal strands. On the contrary, he recognizes that his preferred approach conflicts with precedents reflecting what he terms a "dispute-resolution model." ${ }^{.231}$ But instead of trying to establish a harmony in which each competitor has a proper place, Fiss argues that the specialfunctions approach, to use my terminology, ${ }^{232}$ should be preferred. ${ }^{233} \mathrm{He}$ offers no suggestions as to how cases reflecting a contrary position might be distinguished. Operating at a remove from interprctivist argument, Fiss urges major reforms. ${ }^{234}$ Prudentialism appears to have no place in his vision.

229. See Fiss, supra note 57.

230. Id. at 30 .

231. Id. at 17.

232. Fiss characterizes "the mode of constitutional adjudication" that he ehampions as "structural reform," which he depicts as "distinguished by the constitutional character of the public values [involved], and even more importantly, by the fact that it involves an encounter between the judiciary and the state bureaucraeies." Id. at 2 .

233. See id. at 28-44 (rejecting arguments for the primacy of a dispute-resolution model and asserting reasons to prcfer a vision of the judicial role more receptive to public-rights litigation and structural reform).

234. Interestingly, Fiss casts himself as defending a revolution in legal doctrine already wrought by Brown v. Board of Education, 347 U.S. 483 (1954), and successor cases against a "counterrevolution" by the Burger Court. See Fiss, supra note 57, at 5. But Fiss's notion that his preferred vision of the role of the courts had already triumphed and had only recently come under threat is untenable in light of the deep influence of Marbury's private-rights face. See FALLON ET AL., supra note 5, at 83 ("The Supreme Court has never explicitly embraced the public-rights [or special- 
Fiss's argument is not, of course, the only possible reformist approach to the tensions generated by Marbury's three faces. Whereas Fiss champions a conception of the judicial function that reflects Marbury's specialfunctions face, it would be equally possible for a reformer to prefer the private-rights model. For example, Justice Scalia has suggested that standing doctrine should be organized on this exclusive basis. ${ }^{235}$ Or, conversely, a reformer might conclude that Marbury's private-rights face reflects intellectual naiveté: A sound legal system must attend carefully to consequences both in defining rights and in providing for their enforcement. ${ }^{236}$ To a reformer proceeding in this mode, Marbury's prudential face might illustrate the need for a pragmatic approach to law ${ }^{237}$ more attentive to practical consequences than to logical consistency.

Without rehearsing the disclaimers that followed my attempt to model an interpretivist approach, I would say only that reformism, like interpretivism, should not be expected to satisfy the demands of everyone who adopts an internal perspective on constitutional law. For anyone who must engage in doctrinal discourse under conventions that require the acceptance of entrenched authority and who feels personally implicated in endorsing the validity of the premises from which her arguments proceed, there is no relief from the cognitive dissonance generated by doctrinal tension. Reformism does not so much deny the existence of conflict at the foundations of constitutional law as attempt to avoid it by focusing on what the law ought to be, not on what it is. Nor, in the eyes of those satisfied with an interpretivist approach, is there any need to reject the strategy of seeking doctrinal reconciliation in favor of more explicit reformism. In yet another reasonable view, reformism fails to answer the sensible demand that a perspective on doctrinal tension should not only generate a true empirical account of the state of the law, but also support testable predictions about how judges will decide cases in instances of actual or apparent conflict-a concern to which reformism does not speak at all.

\section{Historicism}

A third response to tension in constitutional thought and doctrine is to return to historical sources and attempt to resolve the disharmony through enhanced historical understanding. Present-day participants in

functions] model of the judicial rule or disavowed the dispute resolution [or private-rights] model. Indeed, its formal pronouncements have been consistently to the contrary.").

235. Scalia, supra note 90 , at $881-85$ (arguing for revisions of standing doctrine to reflect the "traditional requircment that the plaintiff's alleged injury be a particularized one" and tracing his preferred "traditional" approach to Marbury).

236. See generally Louis Kaplow \& Steven Shavell, Fairness Versus Welfare 225-75 (2002) (cmphasizing the importance of costs and benefits in designing optimal legal procedures).

237. The leading champion of legal pragmatism is Judge Posner. See, e.g., Richard A. Posner, The Problematics of Moral and Legal Theory 227-310.(1999) (defining and defending a pragmatic theory of law). 
constitutional discourse view Marbury, like the statutory and constitutional texts that Marbury interpreted, across a broadening temporal and cultural gulf. ${ }^{238}$ Reading the texts through the lens of modern assumptions, influential commentators have concluded that John Marshall must have engaged in willful manipulation of the 1789 Judiciary Act to facilitate a political strategy. ${ }^{239}$ But perhaps their view is mistaken.

A recent article by James Pfander illustrates the possibility that Marbury's seeming contradictions might arise from objective historical misunderstanding. ${ }^{240}$ Based on extensive research, Pfander concludes that John Marshall interpreted the 1789 Judiciary Act correctly. ${ }^{241}$ According to Pfander, it was generally understood during the founding era that "supreme" courts possessed a supervisory authority, to be exercised through writs of mandamus, over governmental officers and lower courts. ${ }^{242}$ When this background understanding is taken into account, Pfander argues, it becomes plain that the 1789 Judiciary Act "confer[red] precisely the sort of freestanding power on the Court that Marshall attributed to it in Marbury." ${ }^{243}$ Building on this foundation, a constitutional historian could imaginably conclude that Marbury included no political or prudential aspect at all. ${ }^{244}$ If so, one source of tension in Marbury would disappear.

Historical inquiries could conceivably purge other tensions as well. For example, one could imagine research purporting to demonstrate that in light of the historical context, Marbury should be understood as committed exclusively to a private-rights approach to constitutional adjudication, ${ }^{245}$ or

238. See generally Lawrence Lessig, Fidelity in Translation, 71 TEx. L. REv, 1165 (1993) (emphasizing the cultural gap between the contemporary world and that of the founders and noting the resulting problems in achieving constitutional understanding).

239. See supra text accompanying notes 69-74.

240. See Pfander, supra note 69.

241. See id. at 1535.

242. See id. at 1518 .

243. Id. at 1535. Pfander also argues that previous commentators on Marbury have looked at a subtly but significantly different version of the statute from the one that Marshall almost surely consulted, with the latter being much more consonant with Marshall's interpretation. See supra note 70.

244. Although Pfander does not reach this conclusion, Robert Clinton does. See Clinton, supra note 74.

245. The Supreme Court appears to have assumed that its dominant, though perhaps not exclusive, limitation of standing to those who have suffered distinct and palpable injuries reflects the original constitutional understanding. See, e.g., FEC v. Akins, 524 U.S. 11, 24 (1998) (asserting that a merely abstract "harm-for example, injury to the interest in seeing that the law is obeyed-deprives the case of the concrete specificity that characterized those controversies which were 'the traditional concern of the courts at Westminster" (quoting Coleman v. Miller, 307 U.S. 433, 460 (1939) (Frankfurter, J., dissenting)) and that alone should therefore be regarded as properly justiciable today); Valley Forge Christian Coll. v. Citizens United for Separation of Church \& State, 454 U.S. 464, 476 (1982) (asserting that standing limitations are "part of the basic charter promulgated by the Framers of the Constitution at Philadelphia in 1787"). Scholars, however, have predominantly rejected the Court's assumption. See, e.g., Richard Pierce, Is Standing Law or Politics?, 77 N.C. L. Rev. 1741, 1765 (reviewing historical studies and eoncluding that "no historical support exists for the proposition that 
perhaps to a historically grounded but now forgotten approach that coherently embodies some but not all aspects of the private-rights and specialfunctions models. ${ }^{246}$ If a project of this kind rendered Marbury wholly selfconsistent, then the historical truth would contain no disturbing dissonance, and subsequent misunderstandings could be characterized as simple errors.

In offering these comments on the possible fruits of historical inquiries, I do not pretend to judge Pfander's conclusions about the best reading of the 1789 Judiciary Act. Neither do I mean to project the success or failure of similar historical inquiries of the kind that I have sketched. I would insist, however, that the historicist project, as I have described it, could not imaginably satisfy the concerns of everyone who is unsettled by apparent contradictions in current constitutional doctrines.

Even if successful in its own terms, historicism could not purge tensions from contemporary doctrine except on the contestable assumption that historical truths uniquely determine current legal meaning and constitutional validity. Full implementation of this assumption would have draconian effects unlikely to be acceptable to anyone. In a closely analogous case that much influences my modeling of historicism, self-styled "originalists" believe that constitutional interpretation should in principle reflect the "original understanding" of relevant constitutional provisions. ${ }^{247}$ Nevertheless, nearly all originalists accept that at least some mistaken decisions must now be aecepted on the basis of stare decisis. ${ }^{248}$ For those adopting this approach, originalism is not a complete constitutional theory, for its implementation requires the development of a normative theory of stare decisis. $^{249}$

Article 11 imposes limits on the types of plaintiffs that can obtain access to federal courts"); Robert J. Pushaw, Jr., Justiciability and Separation of Powers: A Neo-Federalist Approach, 81 Cornell L. REv. 393, 477 (1996) (concluding that the Court has not provided historical support for its view of standing).

246. See e.g., Pushaw, supra note 245 , at $45 \mathrm{I}-52,479-80$ (sketching a "neo-Federalist" theory under which courts have a duty to exercise all jurisdiction eonferred by Congress, the Constitution, or the common law and arguing that when Marbury is set in historical context, it becomes clear that the Court contemplated lawsuits not rooted in private injuries but "necessary to uphold the Supreme Constitution against inconsistent legislation"); $c f$. Raoul Berger, Standing to Sue in Public Actions: Is It a Constitutional Requirement?, 78 YALE L.J. 816, 827 (1969) (maintaining that when the Constitution was adopted, "the English practice in prohibition, certiorari, quo warranto, and informers' and relators' actions encouraged strangers to attack unauthorized action").

247. See, e.g., Raoul Berger, Federalism: The Founders' Design 15-I7 (1987); Robert H. Bork, The Tempting of america: The Political Seduction of the law I43-46 (1990); antonin Scalia, A Matter of Interpretation: Federal Courts and:the Law 38-47 (1997) [hereinafter A Matter of Interpretation]; Antonin Scalia, Originalism: The Lesser Evil, $57 \mathrm{U}$. Cin. L. Rev. 849, 862 (1989); Clarence Thomas, Judging, 45 Kan. L. Rev. 1, 6-7 (1996). For a historiography of originalism, see Barry Friedman \& Scott B. Smith, The Sedimentary Constitution, 147 U. PENN. L. Rev. 1, 11-33 (1999).

248. See, e.g., W. Lynn Creamery, Inc. v. Healy, 512 U.S. 186, 209-10 (1994) (Scalia, J., concurring); Am. Trucking Ass'ns v. Smith, 496 U.S. 167, 204-05 (1990) (Scalia, J., concurring); BORK, supra note 247, at 155-58; SCALIA, A MATTER OF INTERPRETATION, supra note 247, at I38-40.

249. See FAllon, supra note 159, at 15-24. 
The same would almost surely be true of historicism, as I have defined it. If, however, the current constitutional validity of bodies of doctrine developed in reliance (or mis-reliance) on Marbury's three faces does not depend entirely on the historical Marbury's animating assumptions, then historicism cannot by itself resolve all tension and apparent contradiction in constitutional doctrine. To some, it may give comfort to believe that the tensions afflicting constitutional doctrine result from interpretive mistakes, not foundational decisions. To others, however, the salient point will be that perceived tensions in current doctrine continue to exist and, for some, may continue to generate cognitive dissonance. For those whose sense of cognitive dissonance remains, historicism will fail to satisfy a basic desideratum for an approach to perceived doctrinal tensions. Nor, of course, does historicism answer the demands of those who believe that a perspective on tensions in constitutional doctrine should yield predictively valid accounts of how judges actually decide cases.

\section{Realism}

Realism, as I shall use the term, is a perspective concerned solely with achieving a true, empirical account of how judges decide cases, especially in light of perceived tensions in legal doctrine. When the term is used in this familiar way, rather than to describe the historical Realist movement of the 1920s and 1930s, "realist" theories contend that judges decide cases on the basis of their personal values, largely without regard to legal rules. ${ }^{250}$ The most uncompromising realist position, asserting that constitutional norms and legal doctrines have no motivational force, seems psychologically and sociologically implausible. ${ }^{251}$ A more tenable version holds that judges decide cases based on values or ideology when conflicting legal

250. This usage reflects what Brian Leiter characterizes as "the Received View" of legal rcalism: "Legal Realism is fundamentally: (1) a descriptive theory of the nature of the judicial decision, according to which, (2) judges exercise unfettered personal discretion, in ordcr (3) to reach results based on their personal tastes and values, which (4) they then rationalize after-the-fact with appropriate legal rules and reasons." Brian Leiter, Rethinking Legal Realism: Toward a Naturalized Jurisprudence, 76 Tex. L. Rev. 267, 268 (1996).

1 use this definition because it appears to be the understanding of realism that has predominantly influenced current participants in constitutional debates; notwithstanding forceful arguments that this definition fails accurately to reflect the uniting elements in the classic realist writings of the 1920 s and 1930s. See, e.g., Morton J. Horwitz, The Transformation of American Law 1870-1960, at 170 (1992) (arguing that "above all, Realism is a continuation of the Progressive attack on the attempt of late nineteenth century Classical Legal Thought to create a sharp distinction between law and politics and to portray law as neutral, natural, and apolitical'); Leiter, supra at 274-75 (defining the jurisprudence of the historical realists as marked by philosophical commitments to "naturalism," which stipulates that a satisfactory theory of adjudication must flow from empirical inquiry, and pragmatism, which insists that a satisfactory theory must permit successful predictions of what courts will do).

251. See GRIFFIN, supra note 226, at 138 ("Most political scientists and legal scholars ... agree that justiccs ... attempt to follow the law in good faith."); see also Whittington, supra note 226, at 485 (describing a "new institutionalist" school of political scientists who assume that "the law matters to judicial behavior"). 
norms, such as those reflected in Marbury, render the doctrine indeterminate. ${ }^{252}$

In the literature on constitutional law and federal courts law, various writers have adopted largely realist perspectives, notably with respect to the standing and justiciability doctrines that Marbury has inspired and that its faces continue to influence. ${ }^{253}$ For example, Richard Pierce has written that lawyers

can predict judicial decisions in [the standing] area with much greater accuracy if they ignore doctrine and rely entirely on a simple description of the law of standing that is rooted in political science: judges provide access to the courts to individuals who seek to further the political and ideological agendas of judges. ${ }^{254}$

Among its attractions, realism aspires relentlessly to intellectual honesty and mocks fraud and pretense. Realism responds directly to the purposes of those concerned principally with predicting judicial decisions. It also coheres well with familiar and partly cynical beliefs about human motivation, which draw some support from social scientific literature. ${ }^{255}$ Upon embracing realism, some appear to feel a thrill of liberation and an empowerment to act strategically in the service of aims unrelated to doctrinal coherence. ${ }^{256}$ But realism fails to address a number of other demands that doctrinal tension and cognitive dissonance may reasonably spawn.

Defined as a purely empirical theory, realism offers no guidance concerning what a judge, lawyer, or concerned citizen ought to do. ${ }^{257} \mathrm{Con}$ fronted with doctrinal tension that threatens to undermine faith in the possibility of coherent constitutional discourse, a participant in constitutional practice might reasonably test a perspective by its capacity to generate practical guidance, such as that furnished by interpretivism and reformism. Nor does realism speak to the question, which is urgent for many, whether judges have legal obligations, including obligations of the kind identified by interpretivist theories. What lawyers and judges have a constitutional obligation to do is at least partly independent of what is sometimes, or even frequently, done. A perspective that sheds no light on questions of legal obligation is not everyone's cup of tea, nor could purely

252. Cf. Leiter, supra note 250 , at 296 (noting that the classical realists "do not claim that the law is 'globally' indeterminate," but rather that it is "so 'locally,' i.e., in a particular range of cases, particularly those that reach the stage of appellate review").

253. See, e.g., Pierce, supra note 245; Mark V. Tushnet, The New Law of Standing: A Plea for Abandonment, 62 CoRnell L. Rev. 663 (1977); Michael Lewis Wells, The Impact of Substantive Interests on the Law of Federal Courts, 30 WM. \& MARY L. REv. 499, 531-34 (1989).

254. Pierce, supra note 245 , at $1742-43$.

255. See supra text accompanying notes 226-27.

256. See, e.g., Wells, Who's Afraid of Henry Hart?, 14 Const. Comment. 175, 204-05 (1997) (arguing that realism's acknowledgement of the power of "substance" in influencing jurisdictional determinations would generate "a more sophisticated understanding and a more penetrating analysis").

257. For a classic statement of this argument, see HART, supra note 6, at 10-11, 132-44. 
intellectual argument ever make it so. There may also be a strong psychological impetus to resist realism. For some, participation in constitutional practice would be alienating and repugnant if they could not maintain a strong version of the internal point of view, from which constitutional law appears as a genuine source of evaluative and prescriptive norms. Realism's cynical acids threaten to erode the necessary foundations for a strong version of the internal perspective.

\section{Postmodernism}

In contrast with the perspectives that I have discussed so far, postmodernism is not distinctively a strategy for understanding law, but a general intellectual outlook that can be applied to law. There is no canonical definition of postmodernism, and the appropriate definition and its applications are much contested. ${ }^{258}$ I shall use the term in a loose sense embracing two separable strands of thought. The first, poststructuralism, "tends to emphasize the role of language and of language's underlying structures in shaping our understanding of reality and texts." ${ }^{259}$ Poststructuralists maintain that texts are internally unstable, susceptible of alternative and often contradictory meanings. To readers or observers, one meaning may seem clearly correct. If so, poststructuralists see this result as more attributable to social pressures or cultural conditioning than to the texts themselves. ${ }^{260}$ They portray the practices through which meanings are assigned and claims of knowledge validated as activities "infused with social interaction and power." ${ }^{261}$ What is more, they insist that there is no escaping the field of influence. Poststructuralism depicts "the [human] individual not as the subject in control of discourse, but as an artifact produced by discourse." 262

258. See Gary Minda, Postmodern Legal Movements: Law and Jurisprudence at CENTURY's END 2 (1995) ("Postmodernism is an elusive term not easily defined or captured by standard dietionaries or interpretive strategies."). As Minda notes, the effort to capture the postmodernist position in stable propositional terms is in one sense doomed to failure, since the essence of the position is in some sense to deny the "modernist" assumption that there are objectively knowable foundational truths capable of stable statement in propositional form. See id. at 190. It is, however, possible to identify claims that self-styled postmodernists commonly assert.

259. Peter C. Schanek, Understanding Postmodern Thought and Its Implications for Statutory Interpretation, 65 S. CAL. L. REV. 2505, 2514 (1992).

260. MiNDA, supra note 258, at 233 ("Postmoderns understand truth and knowledge as contingent social eonstructions, incapable of being grasped by a fixed, determinate theory or conceptual construct.").

261. See J. M. Balkin, What Is Postmodern Constitutionalism?, 90 MicH. L. REv. 1966, 1972 (1992).

262. Dennis Patterson, Postmodernism/Feminism/Law, 77 CoRnell L. Rev. 254, 276 (1992); see also James Boyle, Is Subjectivity Possible? The Postmodern Subject in Legal Theory, 62 U. CoLo. L. REV. 489, 521 (1991) (charaeterizing the postmodern theory of the "self" as one in whieh " l' am merely the place where things happen"). See generally Pierre Schlag, The Problem of the Subject, 69 TEx. L. REv. 1627 (1991) (exploring difficulties in attempting to give a stable meaning to the notion of "the subject" in contemporary jurisprudence). 
A second strand in postmodernist discourse seeks to eharacterize distinctive features of the contemporary world through comparisons with a predecessor "modern" era. ${ }^{263}$ Examining the implications for eonstitutional law, Jack Balkin describes the postmodern age as one of "mass culture and mediazation," 264 of "fragmentation, diffusion, [and] emphasis on surface (as opposed to substance or as substance itself)." 265 Other commentators have attempted to explain how current literature, architecture, and art are influenced by distinctive trends in world or national politics or popular culture. ${ }^{266}$

Prominent among features tending to unite these two strands of postmodernist thought ${ }^{267}$ is an embrace of irony. As Gary Minda writes, "postmodernism is a condition, an aesthetic, an intellectual style that recognizes and embraces the contradictions and paradoxes it diseovers in traditional conditions, aesthetics, and intelleetual styles." ${ }^{968}$ According to James Boyle, "postmodernism suggests that the best [souree of insight] one could hope for is ironic juxtaposition."269

Marbury lends itself readily to postmodernist analysis: As a text, Marbury is multi-faceted and unstable, reflecting at least three faces. If agreement could ever be reached on its meaning, or even its dominant meaning, that agreement would be culturally eontingent. In contemporary society, it is hardly surprising that there should be an unstable division of views, as case-by-case impulses exert divergent pulls.

Marbury also abounds in irony: Though it is the foundational case for the notion that the Constitution creates rights removed from polities, it was itself a deeply political decision. ${ }^{270}$ Though Marbury famously proclaims

263. See Andreas Huyssen, After the Great Divide: Modernism, Mass Culture, PostModernism 183 (1986) (emphasizing postmodernism's temporal "relational nature"); MiNDA, supra note 258, at 226 ("Postmoderns say that we are now living in the postmodern condition ..., a time that entails new conditions and requires new techniques of investigation.").

264. Balkin, supra note 261, at 1968.

265. Id. at 1969.

266. See, e.g., HuYsSEN, supra note 263, at 183-99 (describing postmodernist approaches to literary criticism, architecture, and art in the 1960s, 1970s, and 1980s).

267. By defining postmodernism in terms of these two strands, 1 have excluded "neopragmatist" thought, which some commentators also group under the postmodernist rubric. See Schanck, supra note 259, at 2514-15; cf. MiNDA, supra note 258, at 229-30 (terming neopragmatism "a close cousin" of postmodernism). Although there are affinities between poststructuralism and some strands of neopragmatism, perhaps the leading neopragmatist legal writer is Richard Posner, see, e.g., POSNER, supra note 237 , whose empiricism and devotion to economic analysis seem radically dissonant with poststructuralism. The kind of legal neopragmatism championed by Posner certainly numbers among the available responses to the tensions in legal doctrine, but it should be defined and evaluated in its own terms, not squeezed under the same rubric with poststructuralism. As l acknowledged at the outset, the range of possible responses to doctrinal tension is vast. Not pretending to analyze or even catalogue all actual or possible theoretical approaches, 1 leave extended discussion of neopragmatism for another day.

268. Minda, supra note 258, at 2.

269. Boyle, supra note 262, at 503.

270. See supra text accompanying notes 69-76. 
that for every right there must be a remedy, William Marbury may have had no remedy, despite having a vested legal right. ${ }^{271}$ Though Marbury asserts that the judicial role is solely to determine the rights of individuals, the opinion furnishes several important rulings irrelevant to the ultimate decision that the Court lacked jurisdiction to vindicate William Marbury's claim to relief. ${ }^{272}$

Beyond Marbury, I have little doubt that postmodernism aptly characterizes some people's experience of constitutional law and of life generally. It is also apparent that some students, lawyers, and law professors delight in the subversive claims and ironic juxtapositions of poststructuralism and feel empowered by postmodernists' insights into contemporary culture and legal practice. Rather clearly, however, postmodernism is too discordant with many people's general experience of life and views about knowledge to be a psychologically plausible option for everyone. Postmodernism holds no promise of establishing doctrinal coherence for those who are troubled by tensions. Nor can it generate normative prescriptions about how to proceed. Indeed, poststructuralism pervasively tends to destabilize the premises that normative argument requires. ${ }^{273}$ In short, although postmodernism may satisfy the purposes and psychological needs of some, its approach to doctrinal tension just as clearly fails to satisfy what I take to be the reasonable demands of others.

271. Although Marbury v. Madison held only that the Supreme Court could not exercise jurisdiction in the original action before it, it is not clear that any court could and would have given Marbury the mandamus relief that he sought. A state court could not have issued a writ of mandamus commanding action by the U.S. Secretary of State. See McClung v. Silliman, 19 U.S. (6 Wheat.) 598 (1821) (holding that a state court lacked jurisdiction of a suit for mandamus against a federal official). Nor did the federal district courts and circuit courts possess mandamus jurisdiction under the 1789 Judiciary Act. See Mclntire v. Wood, 11 U.S. (7 Cranch) 504 (1813). In Kendall v. United States, 37 U.S. (12 Pet.) 524 (1838), the Supreme Court held that the territorial courts of the District of Columbia, apparently alone among the courts of the nation, were empowered to issue writs of mandamus against federal officials. Kendall came thirty-five years after Marbury, however, and it seems highly doubtful that the Court, in the politically charged atmosphere of 1803, would have upheld the authority of the D.C. courts to order mandamus relief for William Marbury against Jamcs Madison. Cf. ElbIs, supra note 20, at 67 (noting "indications" that Marshall "had serious doubts about the political expediency of hearing the motion [in Marbury] in the first place" and asserting that his "main concern ... was to avoid a direct confrontation with the executive department"). In any event, Marbury appears to have abandoned efforts to secure his commission following the Supreme Court's deeision. See Beveridge, supra note 25 , at 125 (reporting that by the time of the Court's ruling, "the term had almost half expired for which Marbury and his associates had been appointed," and "these appointees must have lost all interest in the contest for offiecs of such slight dignity and insignificant emoluments").

272. See supra text accompanying notes 60-61.

273. See Pierre Schlag, Normative and Nowhere to Go, 43 STAN. L. REv. 167, 173-75 (1992) (attacking normative lcgal thought as pervasivcly based on untenable assumptions). I do not mean to suggest that all postmodernists-or cven all poststructuralists-are psychologically disabled from fecling and acting on normative eommitments. Cf. RiCHARD RORTY, CONTINGENCY, 1RONY, AND SOLIDARITY 189 (1989) ("[A] belief can still regulate action, ean still be thought worth dying for, among people who are quitc aware that this belicf is caused by nothing deeper than contingent historieal eircumstance."). My point is only that poststructuralism denies the possibility of objectively valid reasoning from detcrminate moral premises to uniquely correct conclusions. 


\section{Shifting Perspectives}

In describing five strategies for dealing with tension and perceived contradiction in constitutional law, I have not meant to suggest that a selection is necessarily final or irreducible. Taken in their own terms, the strategies attempt to establish different kinds of order or understanding. The type of understanding yielded by one of the perspectives may suffice for some purposes but not for others. For example, it is possible to pursue a realist strategy for purposes of predicting how judges will decide cases, but to believe that constitutional practice is defective or even scandalous in its present state. Someone who is a descriptive and predictive realist might thus adopt a reformist, or possibly historicist, perspective when considering how current doctrinal tensions ought to be dissolved. The same person, when addressing formal legal arguments to a court, might deploy an interpretivist strategy, arguing or believing that there is a doctrinally best way to reconcile a particular apparent tension as a matter of law.

Because it is possible and indeed familiar for the same person to adopt different strategies for dealing with doctrinal tensions at different times, it might be insisted that there are few if any pure interpretivists or realists, for example, but only people who adopt an interpretivist perspective some of the time and for some purposes, and people who sometimes pursue a realist strategy, and so forth. Even if so, however, participants in constitutional discourse commonly have a predominant outlook or orientation of the kind reflected in the interpretivist, reformist, historicist, realist, and postmodernist ideal types - as is suggested by the bodies of literature on which those ideal types are based. Those who speak from these different perspectives often disagree with each other. Insofar as they disagree, the contestants believe that the insights yielded by their strategies are, at the least, more fundamental and illuminating than the claims generated from other perspectives. This phenomenon needs to be explained. My explanation is that familiar differences in perspective often reflect different responses-rooted partly in variables of individual psychology and belief structure-to tension and perceived eontradiction at the foundations of constitutional doctrine.

\section{$\mathrm{V}$ \\ CONCLUSION: MARBURY'S LEGACY}

In this Article I have examined the challenges presented by tensions in constitutional doctrine and constitutional thought. Marbury v. Madison furnishes the paradigm case. At the foundation of constitutional jurisprudence, Marbury exhibits three interesting, powerful, and eonflicting understandings of the necessary and appropriate judicial role: The decision has a private-rights, a special-functions, and a political or prudential face. These 
competing faces continue to influence, and indeed to generate, constitutional doctrine and thought.

Like other tensions in constitutional doctrine, Marbury's divergent faces create cognitive dissonance for many participants in constitutional practice. Doctrinal norms and prescriptions present themselves as authoritative, but their validity depends on their mutual consistency; contradictory premises for constitutional arguments cannot all yield valid conclusions. Among those disposed to view doctrinal formulations as binding norms, the apprehension of doctrinal tension triggers intellectual processes aimed at restoring or establishing coherence. These processes have several interrelated aspects. One aspect involves a search for objective truth or meaning. To grasp the meaning of legal doctrine is to know how to apply it. Because unresolved tension makes correct application impossible, apprehension of tension triggers efforts aimed at resolution. Another aspect of the quest for coherence is purposive. People approach constitutional doctrine and practice with a variety of purposes. These include prediction and persuasion, as well as ordered understanding of legal meaning. The type of coherent understanding that suffices for one purpose may not suffice for others. A further aspect of the search for coherence is psychological, as illuminated by the theory of cognitive dissonance. We all feel a psychological imperative to bring our thoughts, attitudes, and beliefs into harmony. But the harmony that we seek and the dissonance that we experience do not involve our beliefs about law alone. The theory of cognitive dissonance teaches that we strive to reconcile our beliefs about law with our other beliefs and attitudes. According to this theory, the tenability of views about judicial practice and constitutional doctrine will vary with particular people's background beliefs about justice, human psychology, and so forth.

In response to the challenges and the cognitive dissonance created by apprehensions of doctrinal tension, various stratcgies are available. Interpretivism is a strategy for identifying a latent harmony within existing doctrine. Reformism acknowledges current disharmony but promises reconciliation through normatively preferred reforms. Historicism aims to discover normative consistency in the historical foundations of constitutional law and to explain current inconsistencies as the residue of subsequent mistakes. At least two other strategies, realism and postmodernism, are strategies for learning to live with, and possibly find liberation in, perceived doctrinal inconsistency.

The diversity of strategies provokes the question: Which is best? In response, I have argued that none satisfies all of the criteria, some rooted in individual psychology, that a reasonable person might uphold. Choice is likely to be determined more by individual purposes, intellectual bent, and temperament-as shaped by and refracted through the surrounding sociological context-- than by rationally conclusive argument. The wages of 
doctrinal tension are diversity and methodological disagreement in constitutional law.

Marbury is illustrative. We want to know what Marbury means or stands for. Confronted with the case's three faces, the student, professor, judge, or lawyer adopts, probably subconsciously, a perspective from which order can be imposed or disorder can be explained and disarmedperhaps what I have termed an interpretivist, reformist, historicist, realist, or postmodernist perspective. Having made sense of Marbury and its doctrinal legacy for themselves, participants in constitutional practice may then seek to persuade others. As I have emphasized, however, what constitutes the best perspective or understanding depends partly on individual purposes, partly on psychology, and partly on varying background beliefs about a host of matters besides law.

In the absence of a universally best strategy for managing perceived conflict in constitutional law, richness and diversity are the glory of the constitutional culture that Marbury helps to structure. Apparent contradiction and methodological disagreement are also, perhaps inevitably, endemic to Marbury's legacy. ${ }^{274}$

274. Although it has been suggested to me that this conclusion is distinctively "postmodernist," I am inclined to regard this characterization as misleading, though not as flatly false. Much, perhaps all, depends on how the term "postmodernist" is used. As discussed above, I understand the term "postmodernism," as characteristically used in the legal literature, to embrace two separable strands of thought. One pursues poststructuralist analysis of texts, while the other attempts to characterize the distinctive features of a "postmodern" era in contrast with a prior "modern" period. See supra notes 258-66 and accompanying text.

Neither my analysis in this Artiele nor the conclusion to which it leads is in any way poststructuralist. 1 have not claimed that the meaning of all texts is inherently conflicted or unstable. On the contrary, 1 have attempted to give a coherent, stable, and indeed a true account of the state of constitutional doctrine and of the varied predicaments of participants in constitutional practice. I believe that it would also be possible to identify normatively best doctrinal interpretations and normatively best approaches to doctrinal reform, though to do so would be a large and daunting task, far beyond the aim of this Article. My position has not been that all claims of normative truth are inherently conflicted, unstable, or relative, but that not all efforts to understand constitutional law and practice are efforts to identify what is normatively best.

Neither have I suggested, nor do I believe, that my claims about Marbury and its legacy depend in a deep way on peculiar features of contemporary culture or politics. If contemporary doctrine is situated in a "postmodern" world-a characterization that $1 \mathrm{am}$ frankly uncertain whether to embrace-then of course the doctrine that 1 describe is (tautologically) a postmodern phenomenon, as is my commentary. But if all contemporary writing is temporally postmodern, then the label lacks power to discriminate among contemporary works. For the related term "postmodernist" to be illuminating, it would need to refer to something distinctive in perspective or approach that is characteristic of the so-called postmodern age. Both my analysis and my conclusion emphasize tensions, recognize a multiplicity of perspectives, and portray both legal doctrine and human thought as complex and sometimes conflicted. If a tendency to adopt eharaeterizations sueh as these by itself is viewed as suffieient to make an analysis "postmodernist," then the label fairly applies to this Article and its conclusion. I am inclined to resist the postmodernist characterization because 1 fear that it would mislead those who understand the rubric, when applied to legal scholarship, as embracing either poststructuralist premises or a broad rejection of the epistemological assumptions of the "modern" era. 1 understand tension, multiplicity, and complexity as part of the truth about constitutional law and the human condition-not as indications that there is no truth, but only a range of inherently unstable perspectives. 
[Vol. 91:1 